Al1102 516b59

NBSIR 86-3043

NATL INST OF STANDARDS \& TECH R.IC

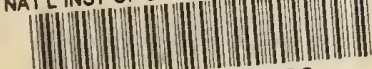

A11102516659

. A/Fusion line shape versus $t$ ' NS

FUSION LIN

TOUGHNESS IN HY-80 GMA WELDS

\author{
T. A. Siewert \\ R. E. Trevisan \\ P. T. Purtscher
}

National Bureau of Standards

U.S. Department of Commerce

Boulder, Colorado 80303

April 1986

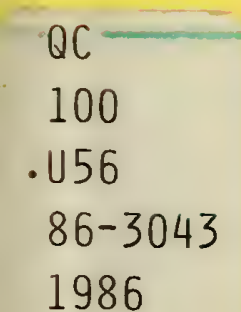



NBSIR 86-3043

\title{
FUSION LINE SHAPE VERSUS TOUGHNESS IN HY-80 GMA WELDS
}

\author{
T. A. Siewert \\ R. E. Trevisan \\ P. T. Purtscher
}

Fracture and Deformation Division

Institute for Materials Science and Engineering

National Bureau of Standards

Boulder, Colorado 80303

April 1986

Supported by

D. W. Taylor Naval Ship R\&D Center

Department of the Navy

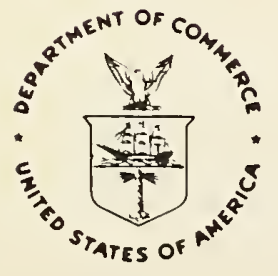

U.S. DEPARTMENT OF COMMERCE, Malcolm Baldrige, Secretary 



\section{CONTENTS}

\section{Page}

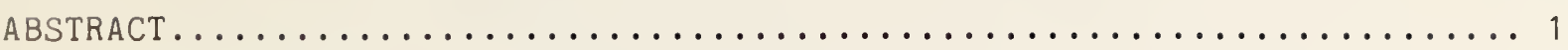

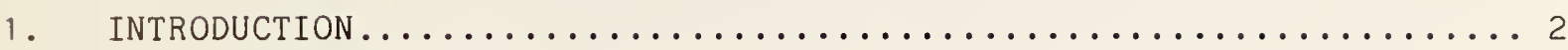

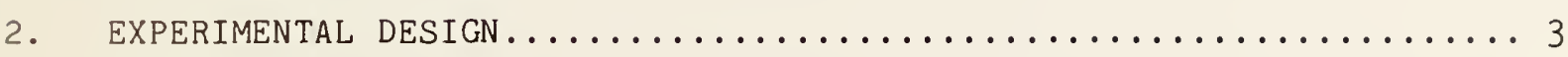

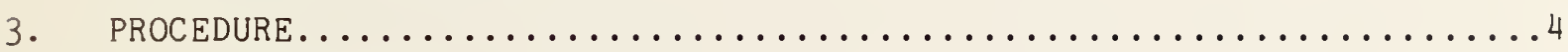

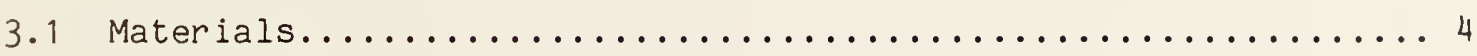

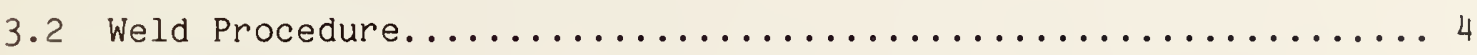

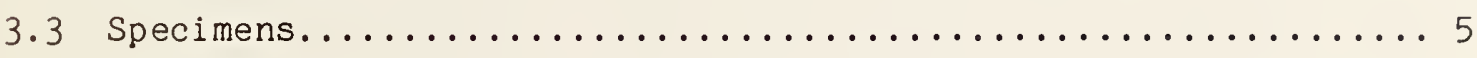

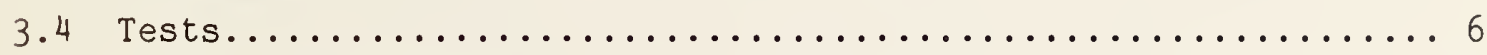

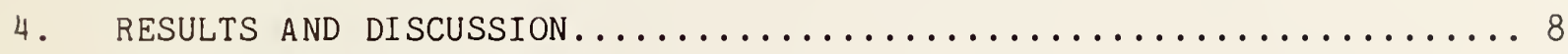

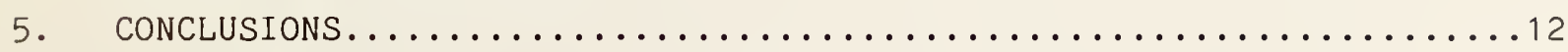

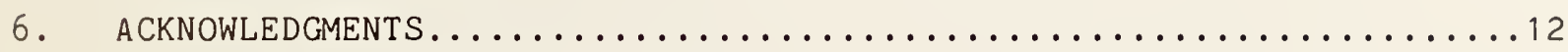

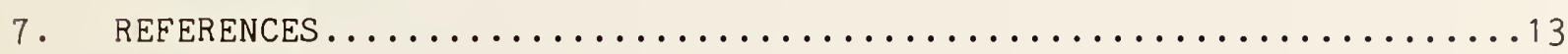

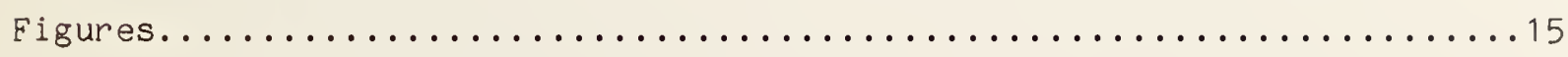

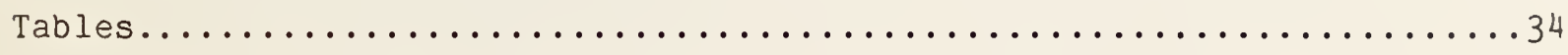



Fusion Line Shape versus Toughness in HY-80

GMA Welds

T. A. Siewert, R. E. Trevisan, and P. T. Purtscher

Fracture and Deformation Division

National Bureau of Standards

Boulder, Colorado

This report describes the effect of the electrode weave procedure on both the fusion-line shape and toughness of reduced-gap gas metal arc (GMA) welds. To study the variation in toughness, four GMA welds were produced in 25-mm-thick HY-80 plate using MIL 100S-1 electrode and following the weld procedure listed in the electrode specification, MIL-E-23765/2C. These four welds were used to compare stringer beads with various weave procedures using both manually controlled and adaptively controlled welding systems.

All-weld-metal Charpy V-notch (CVN) and tensile tests confirmed that these welds met the requirements for MIL 100S-1 electrodes. An increase in strength from 630 to $680 \mathrm{MPa}$ and a decrease in toughness from 135 to $110 \mathrm{~J}$ were observed for the weave patterns with the greatest penetration into the base material.

Testing of compact tension and single-edge-notch bend specimens at room temperature produced $K_{Q}(J)$ fusion-line toughness values of 180 to $315 \mathrm{MPa} \cdot \sqrt{\mathrm{m}}$, with little variation due to weave procedures. Microstructural examination of the crack-initiation region indicated failures occurred and propagated in the HAZ or in the weld metal, rather than along the fusion line. An etching technique revealed a small number of planar flaws on the fusion-line surface that were not detected with radiography. We conclude that weave procedure substantially modifies the fusion-line shape, can change the weld strength, and has little effect on fusion-line or weld toughness.

Key words: electrode weaving; fracture toughness; fusion line; gas metal arch welding; HY-80; mechanical properties; weld properties. 


\section{INTRODUCTION}

Many factors influence the mechanical properties of welds, including welding processes, conditions, and techniques. The magnitude of the effect of changing the welding process, a factor that has been widely studied and reported, can be estimated by comparing reported Charpy $V$-notch (CVN) absorbed energies for HY-80 welds produced by two welding processes. Specification requirements and toughness of welds produced by the GMA and SMA processes are compared in table 1 [1-9]; base material toughness is included for reference $[10,11]$.

Weld toughness can be affected substantially by the welding process, as indicated by the factor-of-two difference between GMA and SMA welds. Also, all the weld toughness values in table 1 are well below those for the base material indicating that the weld toughness controls the fitness of the entire welded structure. Therefore, the weld merits special attention in toughness tests.

Many variables (other than the welding process) affect toughness, but the effects of some have not been measured. This knowledge is necessary for production of welds with optimum properties. The weld weave procedure (especially of reduced-gap welds) is one of these variables for which little information is available and therefore was the subject of this study.

HY-80 is one of the alloys that can have a very complicated interface between the weld and heat affected zone (HAZ) $[12,13]$ owing primarily to the significant compositional differences of the weld metal, the weld metal that is diluted with molten base metal, and the base metal. Also, as the weld cools and begins to solidify, the last layer of the base plate to melt may not have time to mix with the weld metal. This "unmixed zone" has the base metal composition but is subjected to the weld cooling cycle. This rapid cooling may also result in very different mechanical properties in the various weld regions.

Study of the weld's centerline toughness and strength does not reveal the total effect of weld weave procedure on the toughness. Although such tests of the centerline properties form an important part of this study, the toughness of the region near the HAZ and its effect on the failure mode was also measured. The toughness of the HAZ is particularly important for reduced-gap 
welds since the reduced bevel angle reduces the through-thickness dimension of this "unmixed zone" region, making it an easier fracture path if it has low toughness.

\section{EXPERIMENTAL DESIGN}

Welding gun oscillation amplitude and arc penetration into the plate edges forming the sides of the weld joint were the variables in the study. We used two levels of oscillation amplitude (none and $10 \mathrm{~mm}$ ), minimum and high penetration, and two welding systems to produce the four welds. Following the experimental design, summarized in table 2 , we evaluated a progression of electrode weave techniques, extending from a singledimensional mechanical gun oscillator through a fully automated welding system that controlled all three axes of gun motion.

The stringer bead and simple gun oscillator are typical of current manufacturing technology. These systems must be continually monitored, since joint variations due to inaccurate fit or thermal stresses require constant adjustment of position. The fully automated system produced a more consistent joint through adaptive control of the gun position during each weave cycle. Weld 1 was made with a motorized carriage that produced a series of stringer beads. Weld 2 incorporated a 10-mm-wide horizontal weave using the mechanical gun drive to improve fusion into the sides of the weld joint. This weld was produced with minimum penetration of the arc into the sides of the weld joint as was weld 1. Weld 3 was like weld 2 but used a larger oscillation-amplitude to increase penetration of the arc into the sides of the weld joint. This was accomplished by adjusting the horizontal oscillation so that it went further into the side of the weld joint, simulating the action of a welding system that senses the sides of the joint through a reduced arc voltage. Weld 4 was produced with such an automated system, one that followed the weld joint. 
3. PROCEDURE

3.1. Materials

A single heat of 25-mm-thick HY-80 steel plate conforming to MIL-S-16216J Amendment 1 was used for the base material. Its chemical analysis, mechanical properties, and heat identification are listed in table 3. The plate was flame cut into $0.25-\mathrm{m} \times 0.75-\mathrm{m}$ pieces, all aligned with the plate rolling direction so that the HAZ texture would not vary among the welds. These plates were joined in pairs along their $0.75-\mathrm{m}$ sides to form the weld joints. The flame-cut edges and plate surfaces adjacent to the joint were handground to remove the surface oxides. A matching composition backing strip, $0.8 \mathrm{~m} \times$ $25 \mathrm{~mm} \times 5 \mathrm{~mm}$, was used to support the first weld pass.

To facilitate testing of the fusion line, a $45^{\circ}$ included-angle singlebevel joint was used. Figure 1 shows the joint configuration and plate dimensions. The gap between the two plates was $10 \mathrm{~mm}$ at the weld root. Figure 2 shows the plate alignment on the welding table.

The welding gun was angled $20^{\circ}$ to one side of vertical to promote good fusion to both sides of the single-bevel joint and to provide gas nozzle clearance, as shown in figure 3. A single heat of MIL 100S-1 electrode, $1.2 \mathrm{~mm}$ in diameter and conforming to MIL-E-23765/2C was used for all four welds. Its chemical composition, mechanical properties, and heat identification are listed in table 4.

\subsection{Weld Procedure}

The plates (weld joints) were preheated to a temperature between 120 and $150^{\circ} \mathrm{C}$ to prevent hydrogen-induced cracking. The plates were not allowed to cool below $120^{\circ} \mathrm{C}$ before the next pass was begun. If a weld was only partially completed in one shift, it was preheated the next morning before the welding was continued. After the completion of welding, the test plate was allowed to cool in still air, a relatively slow process for the large (80-kg-average) test plates. Welding was performed in the flat (1G) position. Usually, each joint required ten weld passes, and aj.l passes were made in the same direction. Other welding conditions are summarized in table 5 . 
The first pass was produced with the lowest possible current and arc voltage. This produced good fusion at the sides of the joint, but minimized dilution by the plate material, particularly by the joint backing strip. The low dilution reduced the amount of carbon and chromium from the plate material that would $\mathrm{mix}$ in the weld; the resulting lower carbon equivalent ensured formation of a satisfactory low hardness-high toughness microstructure in the first weld pass.

The subsequent passes were performed at a higher current and arc voltage, which produced a more stable and controllable, albeit more penetrating, arc. The greater penetration was primarily into previously deposited weld metal and therefore could be tolerated. The travel speed of these subsequent passes was increased to keep the heat input similar to that of the first pass $(2.7 \mathrm{~kJ} / \mathrm{mm})$.

Special attention was given to the quality of the weld on the vertical side of the joint since this was the side used in fracture testing. The first weld bead for each layer was produced on the vertical side to minimize any incomplete fusion defects due to weld metal flowing ahead of the arc. The heat input was kept constant so that the only differences among the welds were those due to the oscillation pattern. The typical oscillation patterns used in each of the three welds are summarized in table 6 .

\subsection{Specimens}

Specimens for tensile, CVN, compact tension (CT), and single-edge-notch bend (SENB) testing were machined from the welded plates, whose orientations are shown schematically in figure 4. The tensile specimens were prepared according to ASTM specification E 8. The CVN specimens were prepared according to ASTM E 23, and the notches were oriented perpendicular to the plate surface and such that the crack would propagate in the direction opposite to that of welding. The CT and SENB specimens were prepared according to ASTM E 399, and the notches were oriented perpendicular to the plate surface and such that the crack would propagate in the direction of welding. In the following discussion, these specimens are grouped according to whether they were used to evaluate the weld metal (tensile and CVN) or the fusion line (CT and SENB). 
The specimens are identified with a three-term name: the first indicates the weld number, the second indicates the specimen type (e.g., CT, SENB), and the third indicates the specimen number.

\subsection{Tests}

To ensure that the weld variations represented only those due to the weave procedure, we measured both the tensile strength (at room temperature) and CVN toughness $\left(\right.$ at $-51^{\circ} \mathrm{C}$ ) of the undiluted weld metal near the center of the four welds. The results were compared with the mechanical property requirements of MIL-E-23765/2C, confirming that the welding procedure produced high quality welds.

For macroscopic examination of the fusion, specimens from each weld were cut transverse to the welding direction (fig. 4). The samples were polished and macroetched with a 10 percent nital solution. However with this standard technique, only a section of the fusion line could be examined.

Another technique was developed to reveal the fusion-line surface in three dimensions: the four welds (described in section II) made with the type 100S-1 electrode and HY-80 base material, were duplicated using type 309 stainless steel electrode and $H Y-80$ base material with the welding conditions in tables 5 and 6 . These welds were cut from the plate at a point just outside the $\mathrm{HAZ}$ and were dipped in a solution consisting of $100 \mathrm{ml} \mathrm{H}_{2} \mathrm{O}_{2}, 100$ $\mathrm{ml} \mathrm{H}_{2} \mathrm{O}$, and $14 \mathrm{ml} \mathrm{HF}$. This solution dissolved the remaining $\mathrm{HY}-80$ plate and HAZ region but did not dissolve the stainless steel weld metal. Since only the weld metal was left, the fusion-line surfaces were completely exposed (fig. 5).

Using these two macroscopic techniques, we were able to study the entire contact surface between the weld metal and the base material.

Elastic-plastic fracture toughness tests were performed at room temperature on specimens from each of the four welds. Although the base material thickness was $25 \mathrm{~mm}$, the fracture toughness specimen thickness was reduced to $22 \mathrm{~mm}$ in the machining operation and to $15 \mathrm{~mm}$ when side grooved. For the fusion-line specimens, the initial notch and fatigue precrack were located as closely as possible to the fusion line. Figure 6 shows two examples of notch location with respect to the fusion line. For specimen 1-CT-2 ( $\mathrm{fig}$. 6a), the 
notch is on the weld metal side of the fusion line; for specimen 2-CT-1 (fig. 6b), the notch is on the base material HAZ side of the fusion line. It was extremely difficult to locate the tip of the fatigue precrack precisely at the fusion line. However, if the fusion line is truly the weakest region of the weld, then the precrack does not have to be exactly on the fusion line for the crack to grow along the fusion line.

For comparison, the fracture toughness of the base material and center of the weld were measured. In the one base material specimen, the notch was in the $\mathrm{T}-\mathrm{L}$ plane, that is, parallel to the direction of welding. For the two weld metal specimens, the notch was in the center of the weld metal parallel to the direction of welding.

Both SENB and CT specimen configurations were employed in the toughness testing (see fig. 7). Some of the CT specimens were side grooved 20 percent (10 percent on each side) in the hope that the side grooves would limit the crack growth to the region of the fusion line. To produce a fatigue precrack with a relatively straight crack front, the sides of the SENB specimens (not side grooved) were compressed a total of 2 percent ( 1 percent on each side) $[14]$.

Two examples of the fatigue precracks produced by the different test procedures and specimen configurations are shown in figure 8 . Figure $8 \mathrm{a}$ shows a compact tension specimen that was side grooved prior to fatigue precracking. The fatigue precrack front is very irregular and does not meet ASTM E813 requirements. Figure $8 \mathrm{~b}$ shows an SENB specimen that yielded locally in compression prior to fatigue precracking. The fatigue crack front is relatively straight and is acceptable, according to ASTM E813. Note also that the welding flaw had no apparent effect on the growth of the fatigue precrack, but it did have a decided effect on the growth of the overload crack, increasing crack growth in the vicinity of the flaw.

The tests were run on a servohydraulically controlled test machine with a load capacity of $100 \mathrm{kN}$. A computer-aided interactive test procedure was used that calculated the J-integral according to the ASTM E813 test procedure. The change in crack length from the unloading compliance was determined at frequent intervals during the test [15].

After the fracture toughness tests, the fracture surfaces were examined with a scanning electron microscope (SEM) to determine where the crack 
initiated and how it propagated. In the examination, we assumed that the overload crack initiated at the place where the stretch zone is a minimum [16]. For example, consider the fracture surface of the specimen in figure 9. The smooth region near the top is the fatigue precrack, and the rough surface near the bottom is the subsequent fracture. The darker region on the fatigue crack surface adjacent to the subsequent fracture is the stretch zone. Its minimum width, near the center of the figure, is the location of the origin of the fracture.

The location of the crack initiation with respect to the fusion line was determined by the size of the dimples at the initiation site. Figures 10 and 11 show the relative size of the dimples in the base metal and weld metal specimens, respectively. Because the inclusion distribution determines the dimple size and spacing and the weld metal has more inclusions than the base metal, the weld metal fracture surface has more and smaller dimples than the base metal fracture surface. Thus, it was possible to identify the material at the crack initiation.

The HY-80 weld cross section used for the macrographic study was also surveyed for microhardness. The hardness was measured along a line normal to the fusion line and extending from the undisturbed base material, through the $\mathrm{HAZ}$ and fusion line, and into the weld. The individual measurements were taken at small intervals to indicate the trends in regions where the hardness varied over a short distance (such as the HAZ and fusion line); larger measurement intervals were chosen in the other regions. The fusion line was chosen as the origin when comparing the hardness traverses, with measurements in the weld being assigned negative distances and the measurements in the base material being assigned positive distances from this point. These measurements were performed to determine the relative hardness (and so the relative strength and toughness) of the fracture path.

4. RESULTS AND DISCUSSION

The tensile test results for the weld metal and the specification requirements (MIL-E-23765/2C) are listed in table 7 . Both the ultimate tensile strength (UTS) and yield strength in the weld metal met the specified values. In the specimens (weld 3 and 4 ) where the most severe weave pattern 
was used, we noticed higher yield strength and UTS than in the other samples. The 8 percent higher strength is attributed to the effects of greater base material dilution with these procedures.

Table 8 presents the substantial compositional differences between the base material and the welding electrode (taken from tables 3 and 4). When the weld, already rich in manganese, is enriched with carbon and chromium through dilution, the weld's carbon equivalent is increased substantially, leading to a higher strength deposit.

The measured CVN test results for the weld metal, as well as the specification requirements (MIL-E-23765), are shown in table 9. The weld metal toughness values meet the specification requirements. The welds that had the highest penetration into the side walls (welds 3 and 4 ) had 20 percent lower absorbed energy than the other specimens. The same behavior can be seen in the lateral expansion results. Again, the increased carbon equivalent due to dilution by the base material is the cause, and the higher strength microstructure has a lower toughness.

The low-magnification photographs of transverse sections through the four welds in figure 12 show the effects of horizontal arc oscillation on the macrostructure. When oscillation was not used ( $f i g .12 a$ ), the beads were more rounded than when oscillation was used (fig. 12b,c,d). Figure 12 also reveals that the HAZ thickness and fusion-line shape are the same for all four welds. Metallographic studies did not show evidence of porosity or incomplete fusion in the weld.

Figure 13 shows the fusion-line surfaces for the four welds produced using stainless steel filler material in order to characterize the texture of the fusion line. This technique shows the entire surface clearly; only a line of which is revealed in conventional transverse sections. The stainless steel weld metal has a different composition and therefore a different viscosity and wetting character than the ferritic welds; however, the fusion surface is representative of the welding arc action (which was duplicated) and the weave pattern. The smooth fusion-line surface of weld 1 (stringer bead technique) is vastly different than the convoluted fusion-line surface for the three welds with the weave techniques. Only small differences are apparent among the three weave patterns; therefore, variable penetration into joint walls and the difference between semiautomatic and adaptive control had 
little effect on the fusion-line surfaces for these tests. The spacing and height of the convolutions (ripples) should have a substantial effect on the toughness of welds in which the fusion line is the critical crack path. Such ripples tend to lengthen the fracture path (and thus increase the fracture toughness) and tend to turn the running crack into the tougher weld or base material.

Careful examination of the fusion-line surfaces reveals small, flat areas that could be interpreted as insufficient fusion flaws. These regions, comprising less than 2 percent of the fusion-line surface area, were not observed on the weld radiographs of transverse sections. They could be the weld flaws that were seen on several of the fusion-line fracture surfaces.

The fracture toughness test results are summarized in tables 10 and 11 . The values are referred to as $J_{Q}$ and $K_{Q}(J)$, rather than $J_{I c}$ and $K_{I c}$, because the results do not meet all the validity requirements specified in ASTM E813. In most of the tests, the deviations from the standard test procedure are considered to have only minor effects on the results, and the values reported should be representative of the true fracture toughness. However, the specimens with the highest $\mathrm{J}_{\mathrm{Q}}$ values, above $385 \mathrm{~kJ} / \mathrm{m}^{2}$, did not meet the minimum thickness requirements and the values are dependent on specimen size. Therefore, they are labeled invalid in the comments column. Although the values are, strictly speaking, invalid, they still give an indication of high toughness.

For the specimens with the notch in the vicinity of the fusion line, $\mathrm{K}_{\mathrm{Q}}(\mathrm{J})$ values varied from 180 to $315 \mathrm{MPa} \cdot \sqrt{\mathrm{m}}$. The large scatter in the data depended more on the exact location of the notch with respect to welding flaws and the fusion line rather than on the weld weave procedure.

The specimens from the center of the welds (1-CT-WM and 4-CT-WM), one from a straight weld and the second from a weave weld, were both very tough, but the results were invalid for the specimen sizes used. The same result was found for the base metal specimen 4-CT-BM.

The fracture initiation location with respect to the fusion line was determined by studying the fracture surfaces, which are well defined in figures 10 and 11. From this SEM examination, we can also follow the crack propagaiion. The results are summarized in tables 10 and 11 . Figure 14 shows one typical pattern, where the crack initiated in the base metal HAZ 
and propagated into the weld metal (identified in table 10 by HAZ + WM). This type of crack development occurred in specimens 2-CT-1 and 3-CT-4. Figure 15 shows another typical pattern, where the crack initiated at a weld flaw and propagated in the weld (WM flaw). This type of pattern occurred in specimens 1-CT-2, 1-CT-3, 3-CT-1, 3-CT-2, 1-SENB-1 and 3-SENB-1. Figure 16 shows the third typical pattern where the crack initiated and propagated in the weld $(W M)$. This pattern of crack development was present in specimens 4-CT-1, 4-CT-2, 2-SENB-1, and 2-SENB-2.

The quantity of $\mathrm{J}_{\mathrm{Q}}$ is a measure of fracture initiation resistance, the beginning of ductile tearing. Some of the specimens had low values of $J_{Q}$, but typically that low value can be attributed to the presence of welding flaws. All the specimens exhibited an extremely steep tearing slope for crack growth regardless of their $\mathrm{J}_{\mathrm{Q}}$ value. Figures 17, 18, and 19 are representative $J-R$ curves of three different types of crack growth, distinct from the three types of crack initiation described above. For specimen 1-CT-2, the crack initiated at a welding flaw and grew with an assist from the flaw. As the crack front passed the flaw, it blunted. The J-R curve for this specimen, figure 17 , shows a relatively low value for $J_{Q}$, a shallow initial tearing slope followed by a much steeper tearing slope that corresponds to the crack blunting. For specimen 1-SENB-1, the crack initiated in the weld near the fusion line at fine inclusions and grew through the weld. The $\mathrm{J}-\mathrm{R}$ curve, figure 18 , shows a relatively good $\mathrm{J}_{\mathrm{Q}}$ value with a steep tearing slope. For specimen 2-SENB-2, the crack initiated near the fusion line of the weld, again at fine inclusions, and then grew through the weld metal. The $J-R$ curve, figure 19, shows a very high toughness--enough to invalidate the test results for this size specimen. These test results indicate that welding flaws near the fusion line do not promote brittle crack growth behavior in HY-80 welds tested at room temperature.

Table 12 lists the hardness traverses across the four welds. The traverse started in the weld (distance from the fusion line was chosed to be negative) and continued through the HAZ into the base material. The fusion line and HAZ immediately adjacent have hardnesses intermediate between those of the weld and the rest of the HAZ. Therefore, the strength and toughness values are also be expected to be intermediate, and this region is 
not expected to be a critical failure path. These results support the detailed fracture mechanics testing.

\section{CONCLUSIONS}

1. Four welds, produced with both semiautomatically and adaptively guided welding systems and several weave procedures, all met the mechanical property requirements of MIL-E-23765/2C. The welding system itself did not substantially affect the weld strength or toughness.

2. The most substantial differences among the welds were attributed to weld penetration: the higher penetration level increased the weld strength from 630 to $680 \mathrm{MPa}$ and reduced the CVN toughness from 135 to $110 \mathrm{~J}$.

3. Variations in crack initiation location and crack growth ( $J-R$ curve) were not related to the weld weave procedure. Study of other weld parameters is needed to find the source of these variations.

4. The region near the fusion line of HY-80 welds has a lower toughness at room temperature than the $\mathrm{HAZ}$ or center of the weld, due to dilution by the base material. However, the failure mechanism is ductile in all cases with reasonably good values for $\mathrm{J}_{\mathrm{Q}}$, the energy to initiate a crack.

5. The lowest values of $J_{Q}$ measured were associated with welding flaws.

6. The slopes of the tearing 1 ines in the fracture-toughness tests were quite steep, indicating a high resistance to crack growth.

7. Microhardness traverses indicated that the fusion line had hardness values intermediate between those of the weld and the HAZ.

8. The entire fusion-line surface can be revealed by simulating the weld with a stainless steel electrode and then dissolving the base material.

6. ACKNOWLEDGMENTS

This effort was supported and monitored by Mr. C. A. Zanis of the D. W. Taylor Naval Ship R\&D Center under Program Element 62761N, Task Area SF61541001. The contributions of Mr. D. P. Vigliotti as technician on this project are gratefully acknowledged. The base material was furnished by Mr. R. Brooks of Phoenix Steel. 
7. REFERENCES

[1] Military Specification, Electrodes and Rods - Welding, Bare, Solid, or Alloyed Core, Low Alloy Steel, MIL-E-23765/2C (SH), June 1983. Washington, D.C.: NAVSEA, Dept. of Navy.

[2] Military Specification, Electrodes, Welding, Mineral Covered, IronPowder, Low-Hydrogen, Medium, High Tensile and Higher-Strength Low Alloy Steels, MIL-E-22200/10A(SH), July 1983. Washington D.C.: NAVSEA, Dept. of Navy .

[3] Telford, R. T. 1965. New applications for gas metal arc welding and short circuiting transfer, Welding Journal 44: 169.

[4] Flax, R. W.; Keith, R. E.; and Randal1, M. D. 1971. Welding the HY Steels, ASTM STP 494. Philadelphia: American Society for Testing and Materials.

[5] Airco Shielded Metal Arc Electrode Data, Airco, 1985. Cleveland, Ohio.

[6] Atom Arc Iron Powder Low Hydrogen Electrodes (AR-AA2-20M-579F), Alloy Rods, Hanover, Pennsylvania.

[7] Hobart Electrodes, Wire - Flux (EW-518), Hobard Brothers Company, 1983. Troy, Ohio.

[8] Weldirectory: of Electrodes for Carbon and Alloy Steel (M210), The Lincoln Electric Company, 1985. Cleveland, Ohio.

[9] McKay Selector: A guide to the Selection and Use of McKay Welding Electrodes and Wires $(75 \mathrm{~F}-2)$, Teledyne McKay, 1984. York, Pennsylvania.

[10] Military Specification, Steel Plate, Alloy, Structural, High Yield Strength (HY-80 and Hy-100), MIL-S-16216J(SH), April 1981. Washington, D.C. NAVSEA, Dept. of Navy.

[11] Certified Material Test Report from Phoenix Steel Corporation, Claymont, Delaware, for Heat $54994 \mathrm{HY}-80$ base material used in this study.

[12] Savage, W. F.; Nippes E. F.; and Szekeres, E. S. 1976. A study of weld interface phenomena in a low alloy steel. Welding Journal 55: 260-S.

[13] Baeslack, W. A., III; Lippold, J. C.; and Savage, W. F. 1979. Unmixed zone formation in austenitic stainless steel weldments. Welding Journal 58: $168-\mathrm{S}$. 
[14] Towers, O. L. and Dawes, M. G. 1985. Welding Institute research on the fatigue precracking of fracture toughness specimens. Elastic-Plastic Fracture Test Methods: User's Experience. ASTM STP 856, eds. E. T. Wessel and F. J. Loss: 23. Philadelphia: American Society for Testing and Materials.

[15] Tobler, R. L.; Read, D. T.; and Reed, R. P. 1981. Strength/toughness relationship for interstitially strengthed AISI 304 stainless steels at $4 \mathrm{~K}$ temperature. Fracture Mechanics: Thirteenth Conference. ASTM STP 743, ed. R. Roberts: 250. Philadelphia: American Society for Testing and Materials.

[16] Kobayashi, H.; Nakamura, H.; and Nakazawa, H. 1983. Comparison of JIc test methods recommended by ASTM and JSME. Elastic-Plastic Fracture Test Methods: User's Experience. ASTM STP 856, eds. E. T. Wessel and F. J. Loss: 3-22. American Society for Testing and Materials. 


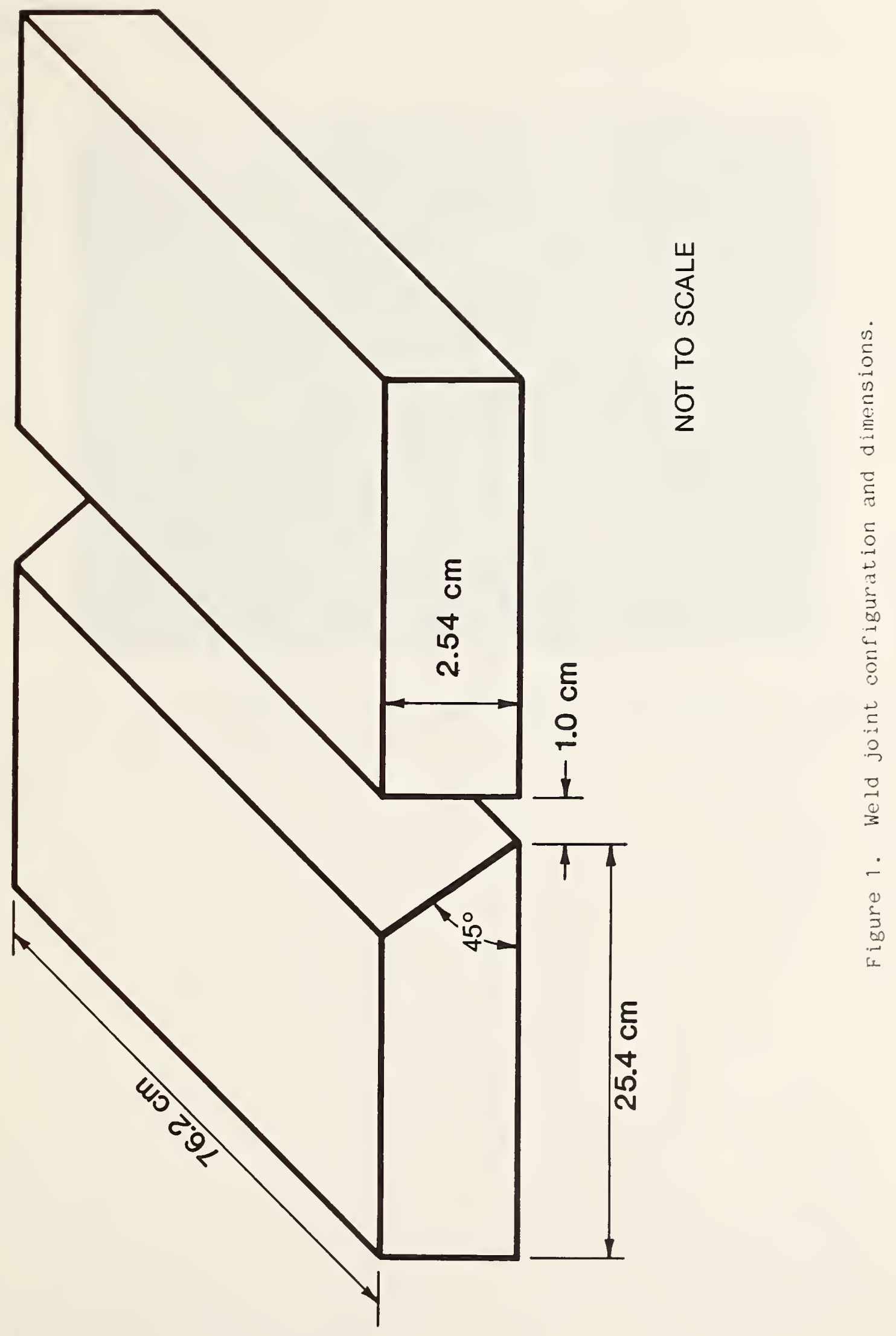




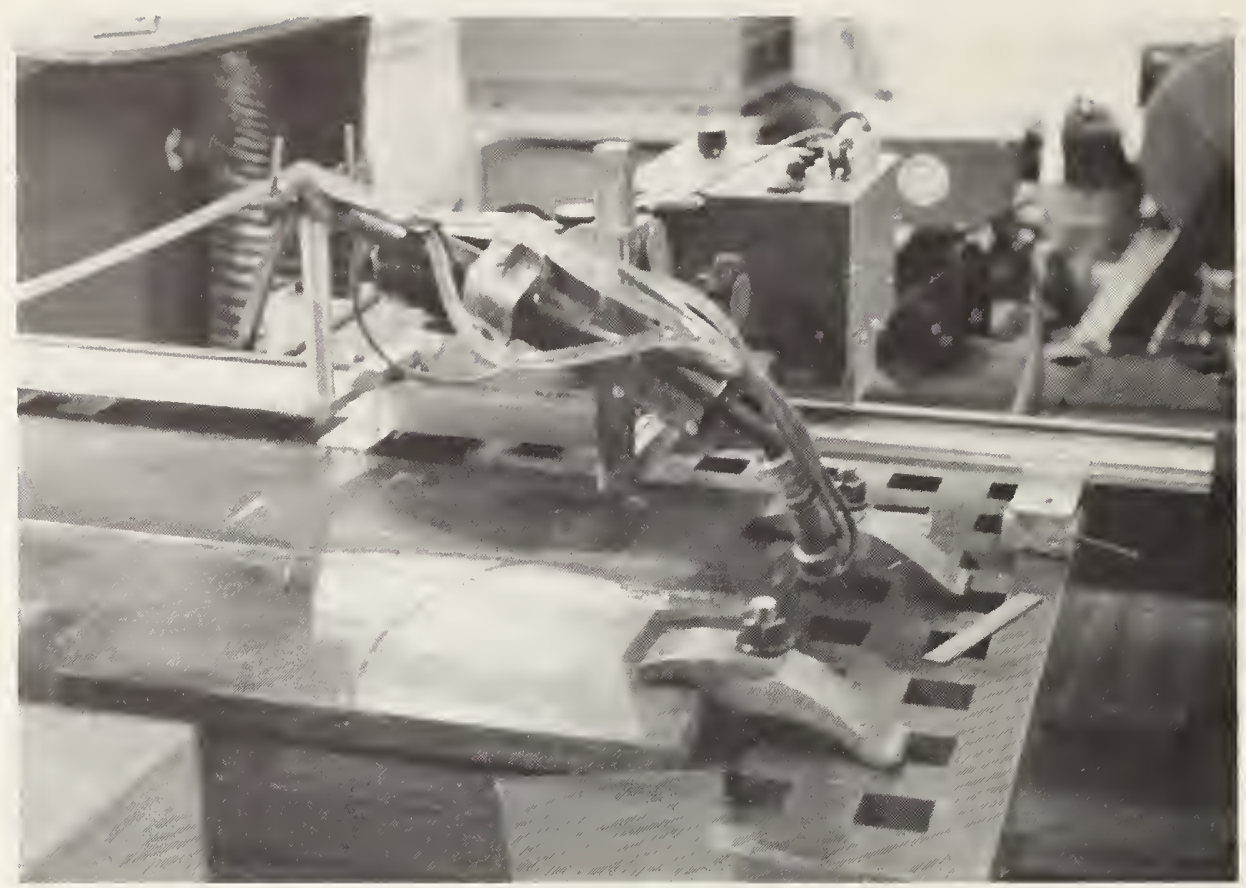

Figure 2. Plate alignment on the welding table. 


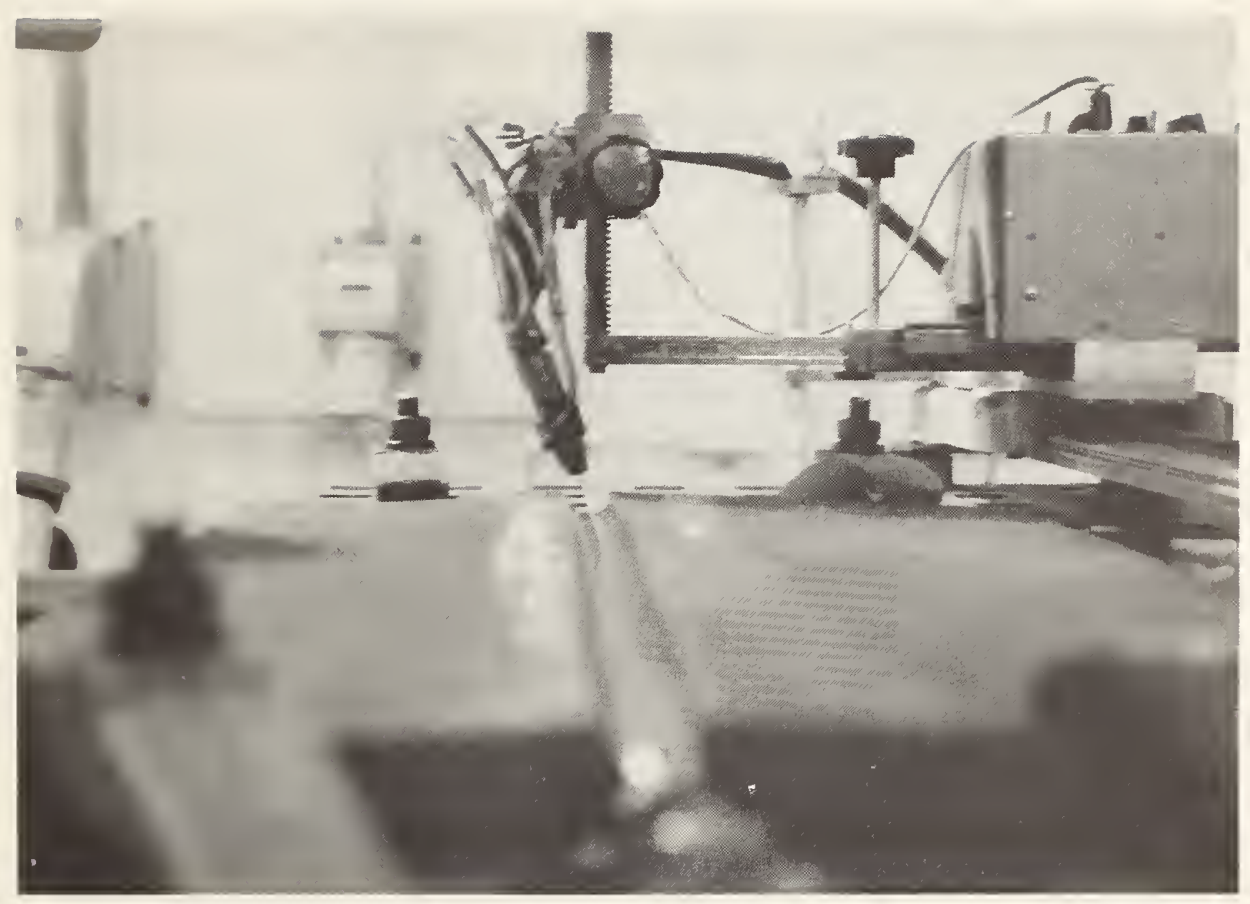

Figure 3. View from the end of the weld illustrating the $20^{\circ}$ rotation of the torch to promote good fusion with both sides of the joint. 


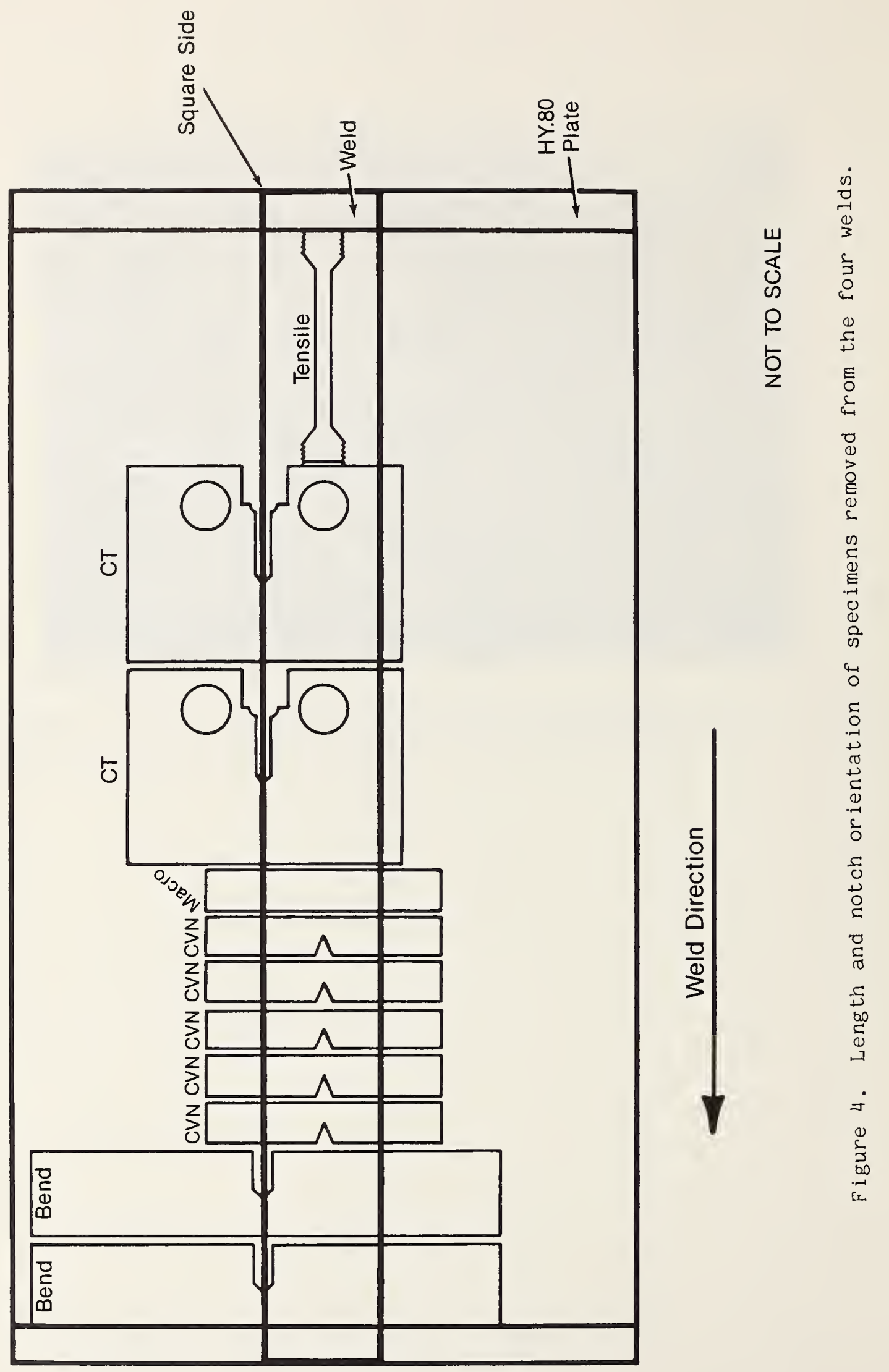




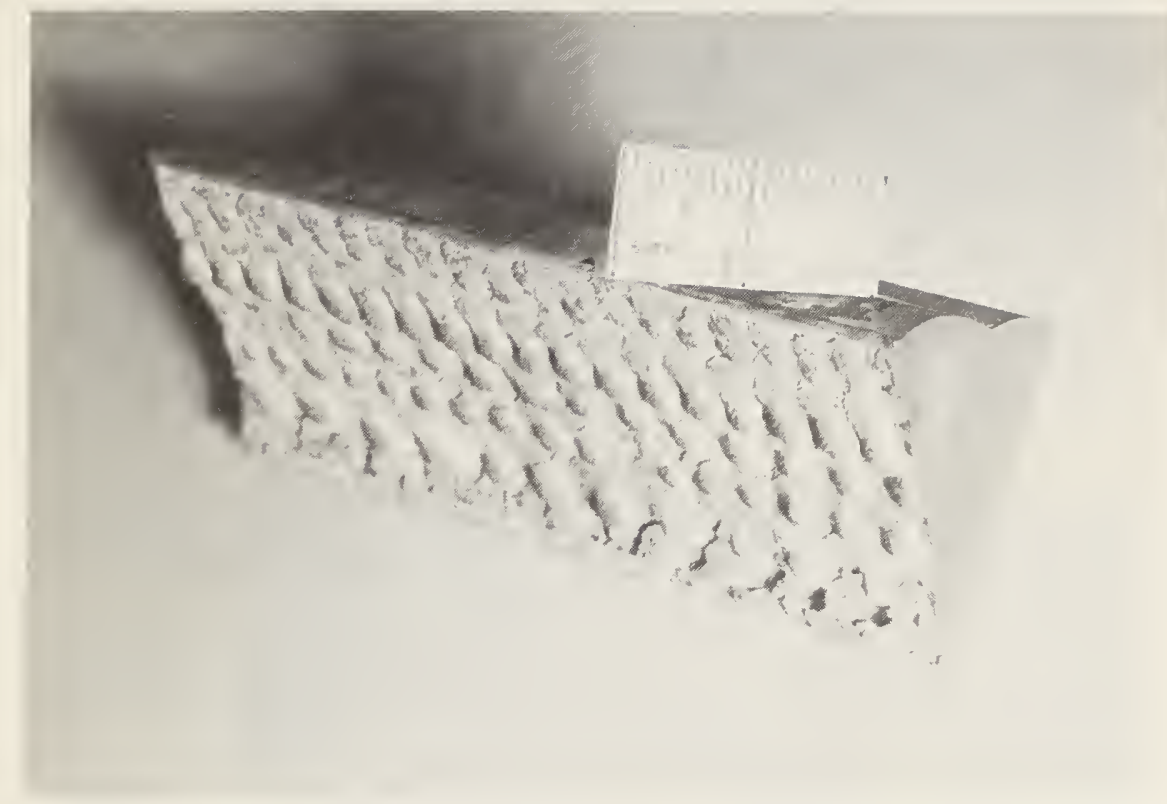

Figure 5. View of the stainless steel weld metal showing the fusionline surface after the HY-80 base plate was dissolved. 


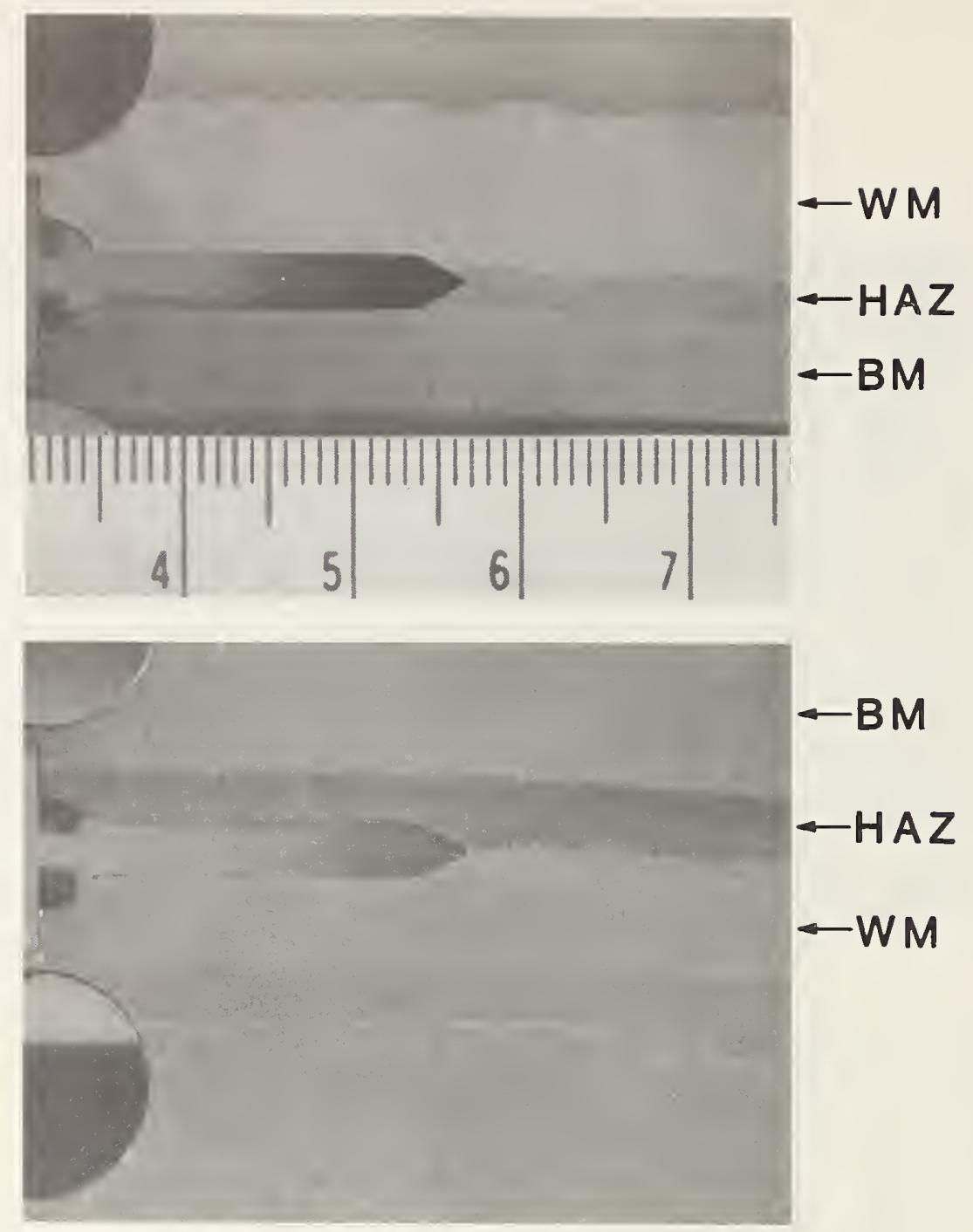

Eigure 6. Two examples of notch location, deviating slightly from the fusion-line. 


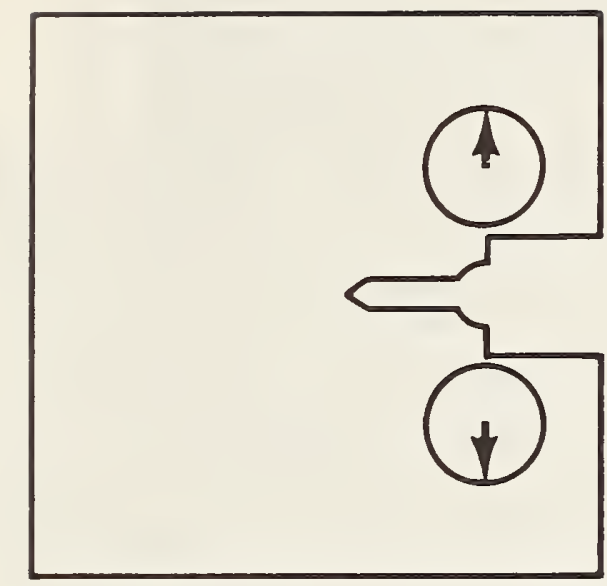

COMPACT TENSION SPECIMEN

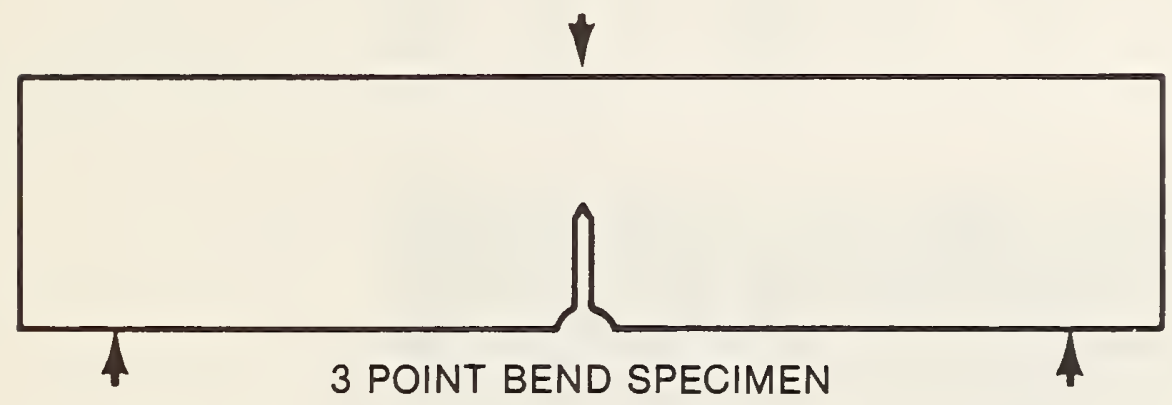

Figure 7. Single-edge-notch bend and compact tension specimen configurations. 


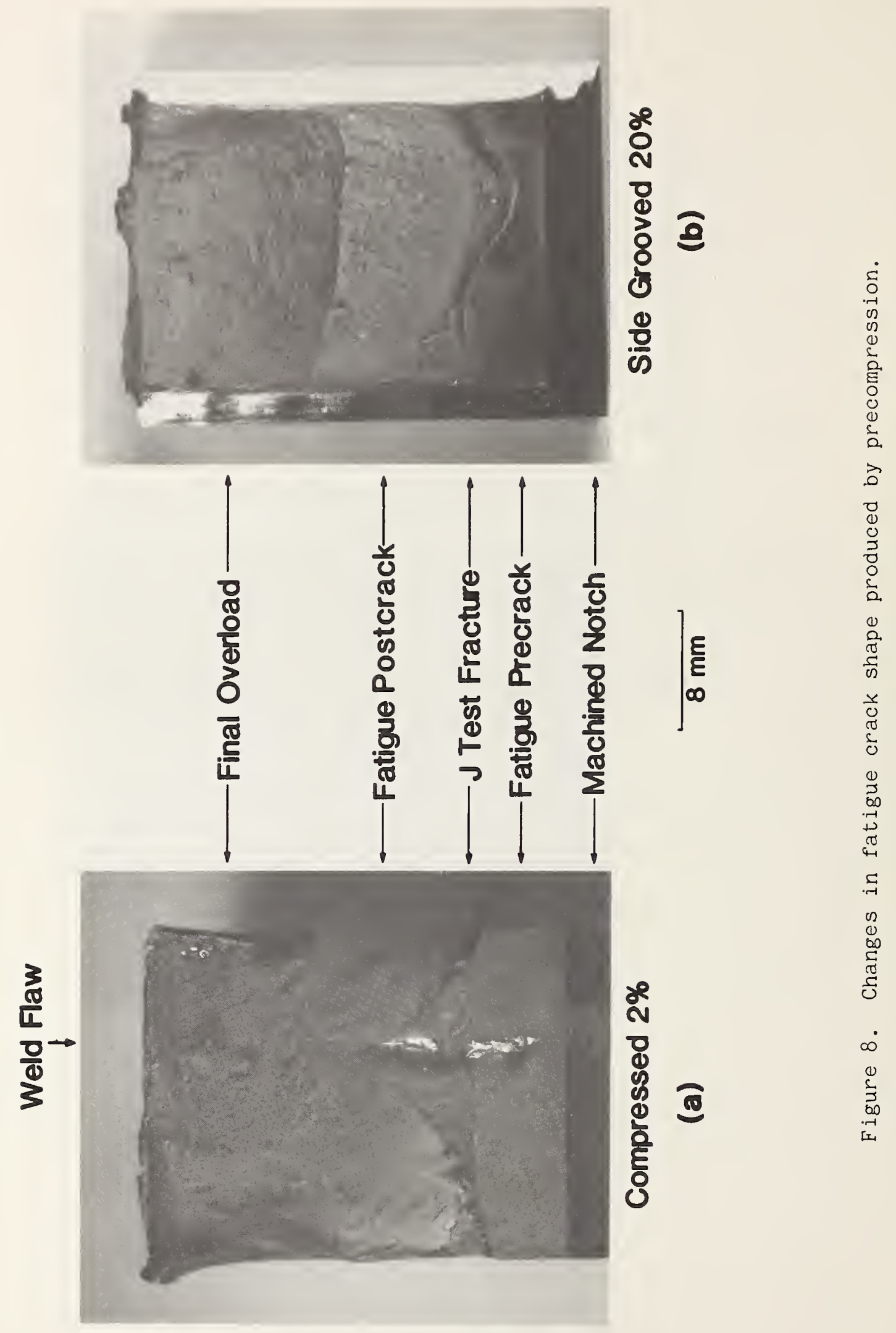




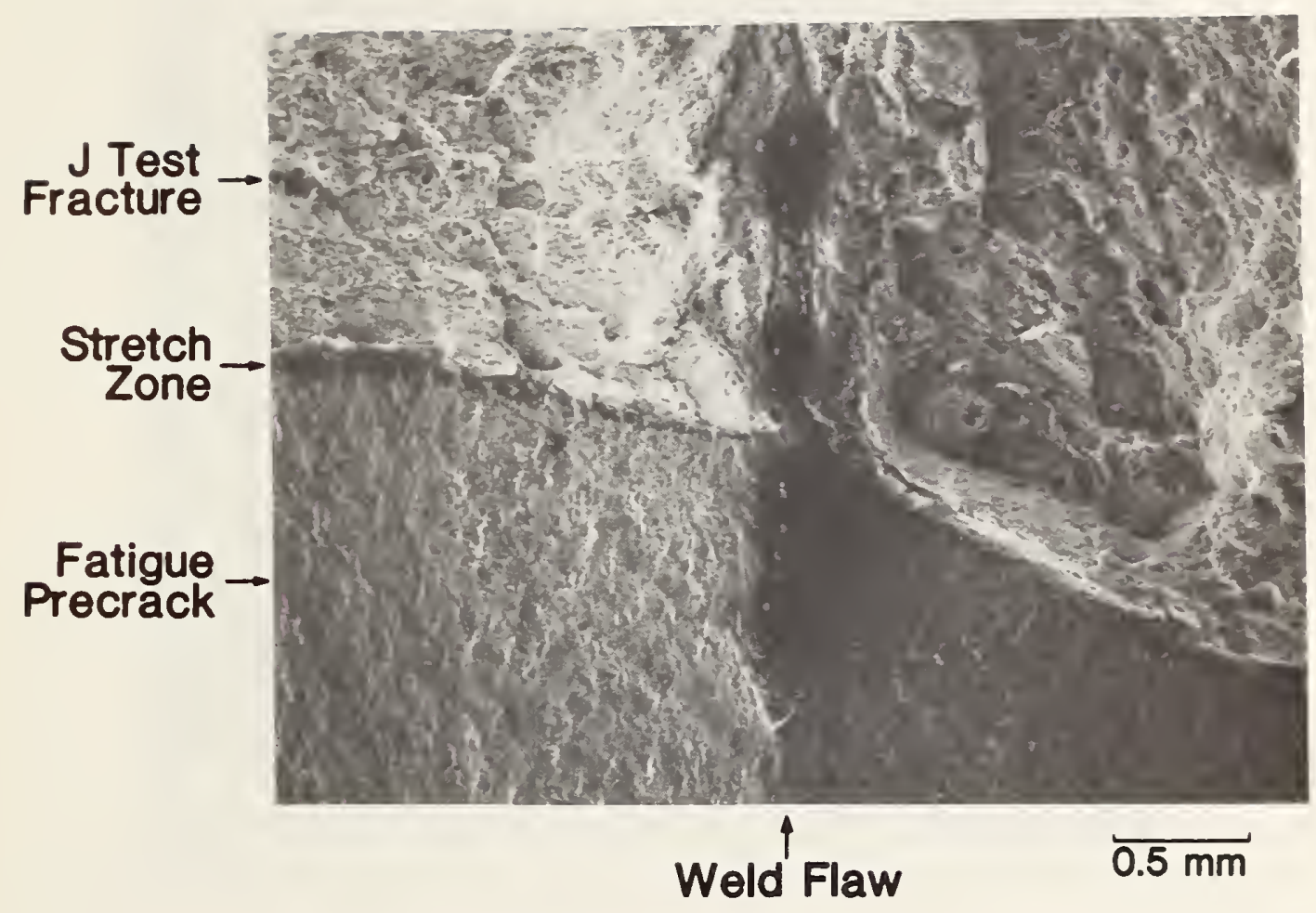

Figure 9. Fracture surfaces showing crack initiation. 


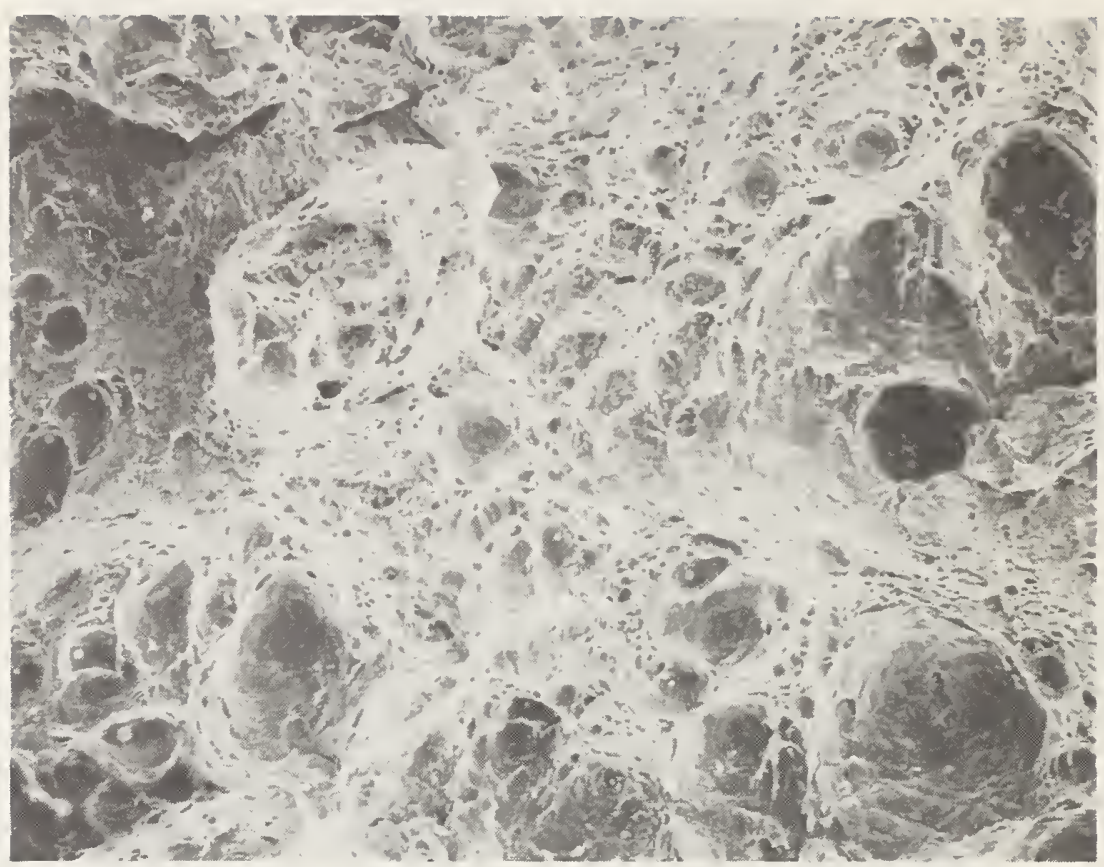

Figure 10. Fracture surface dimple size in the base metal. 


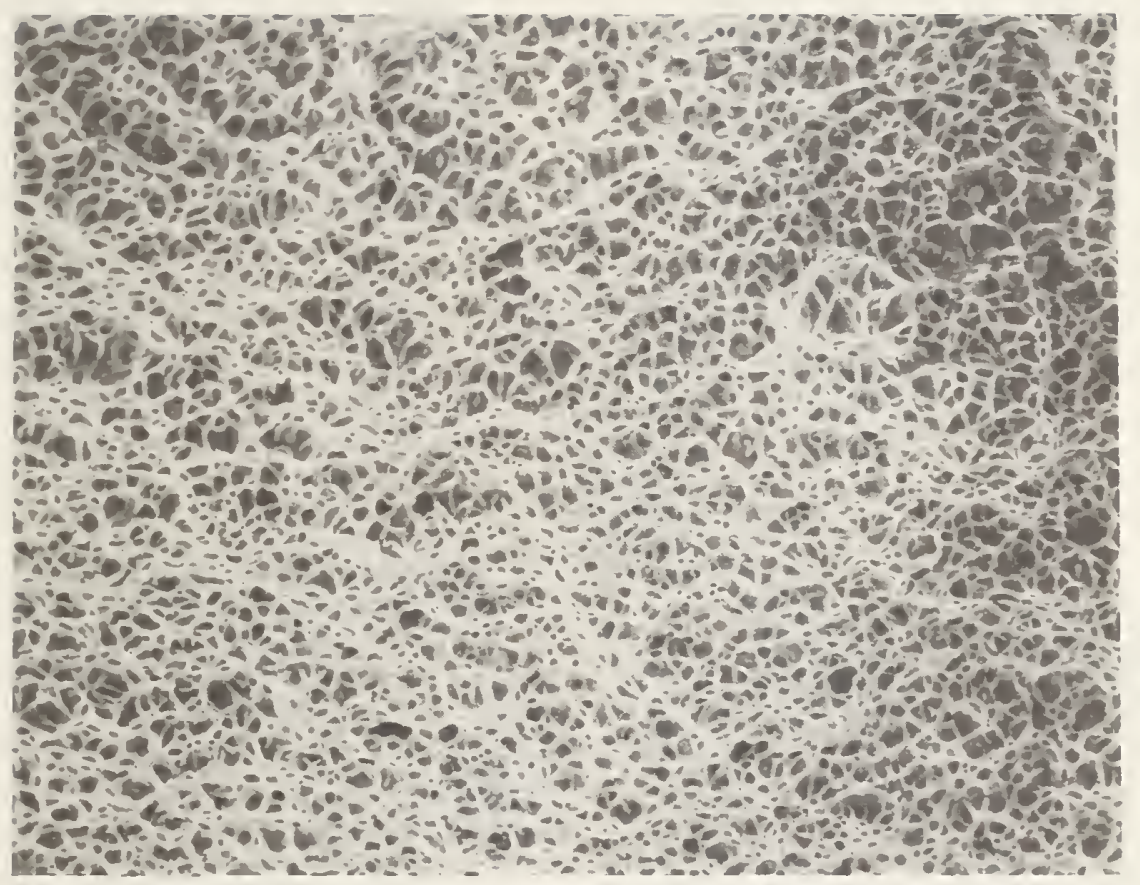

Figure 11. Fracture surface dimple size in the weld. 


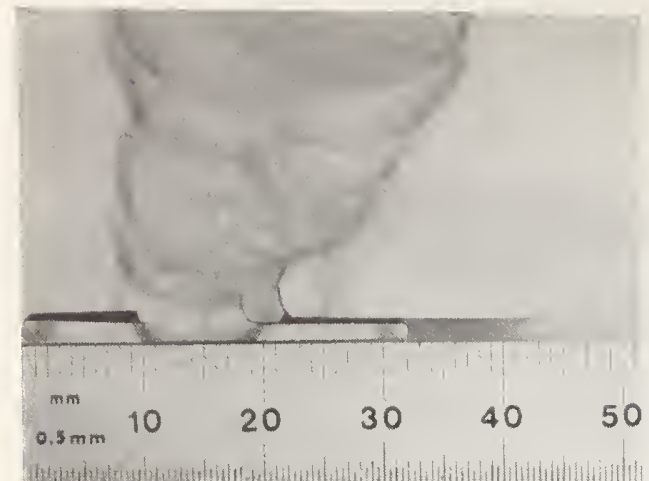

Weld 1

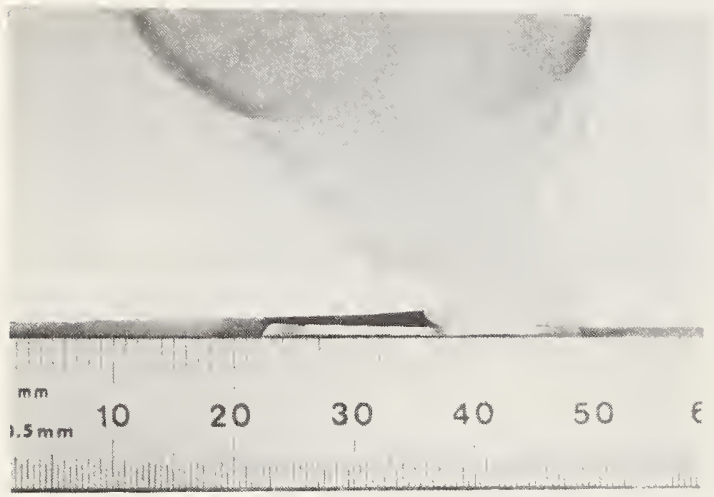

Weld 3

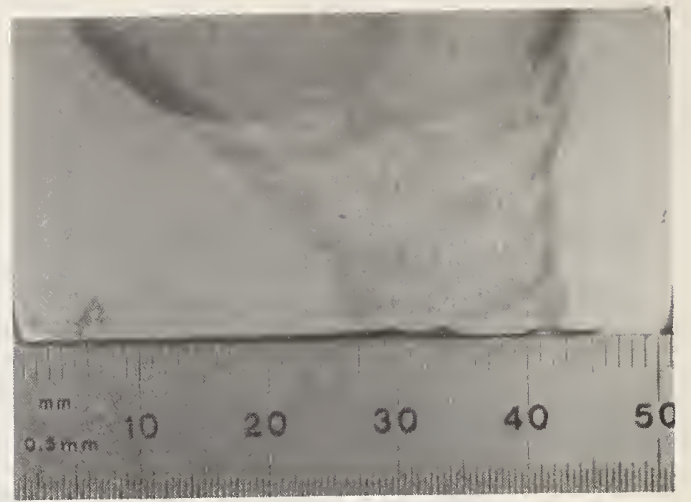

Weld 2

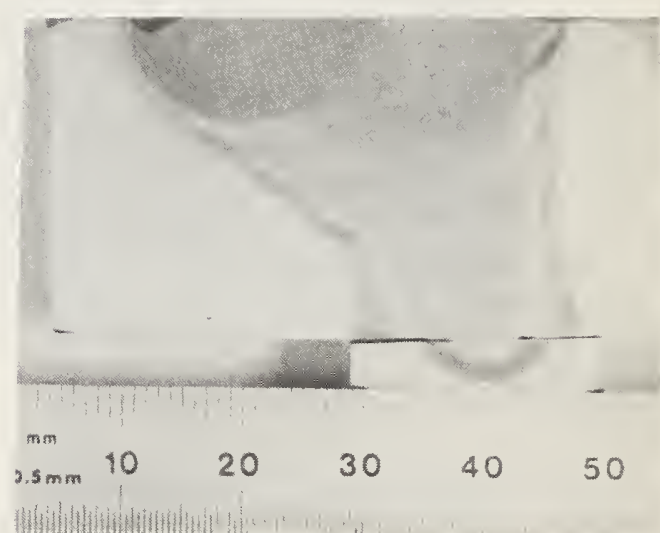

Weld 4

Figure 12. Macrostructures of cross sections of the four welds. 

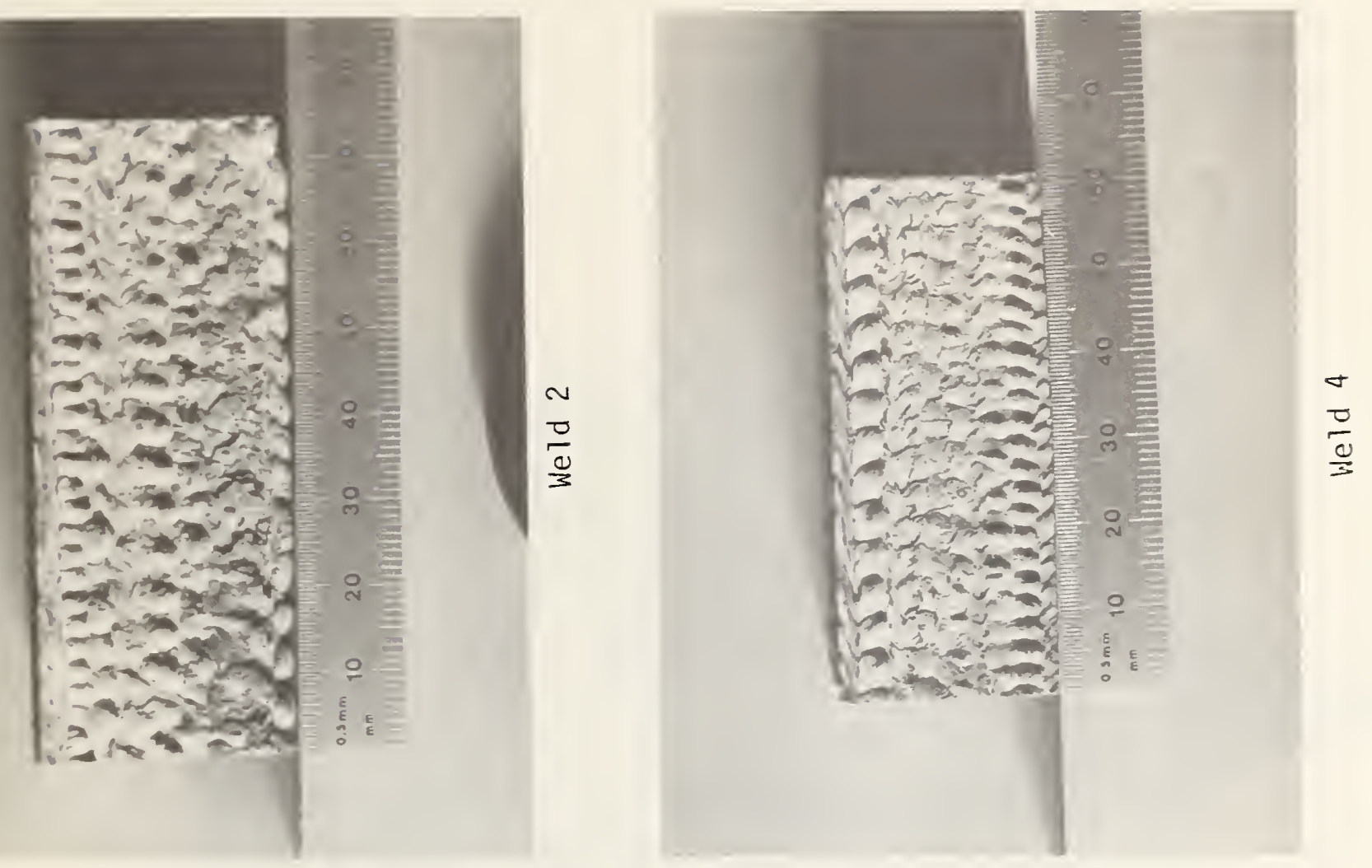

0
0
0
0
0
0
1
0
0
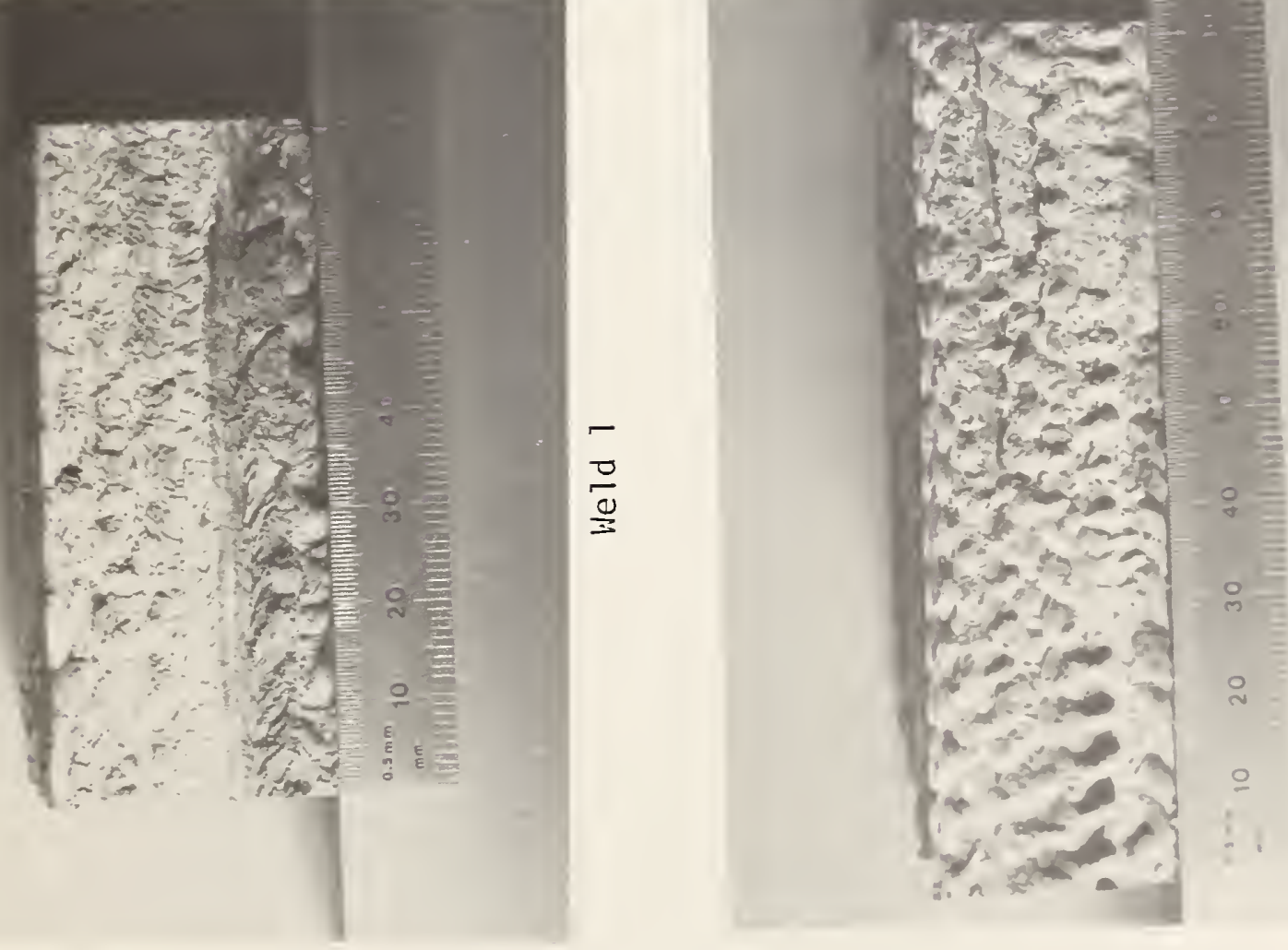


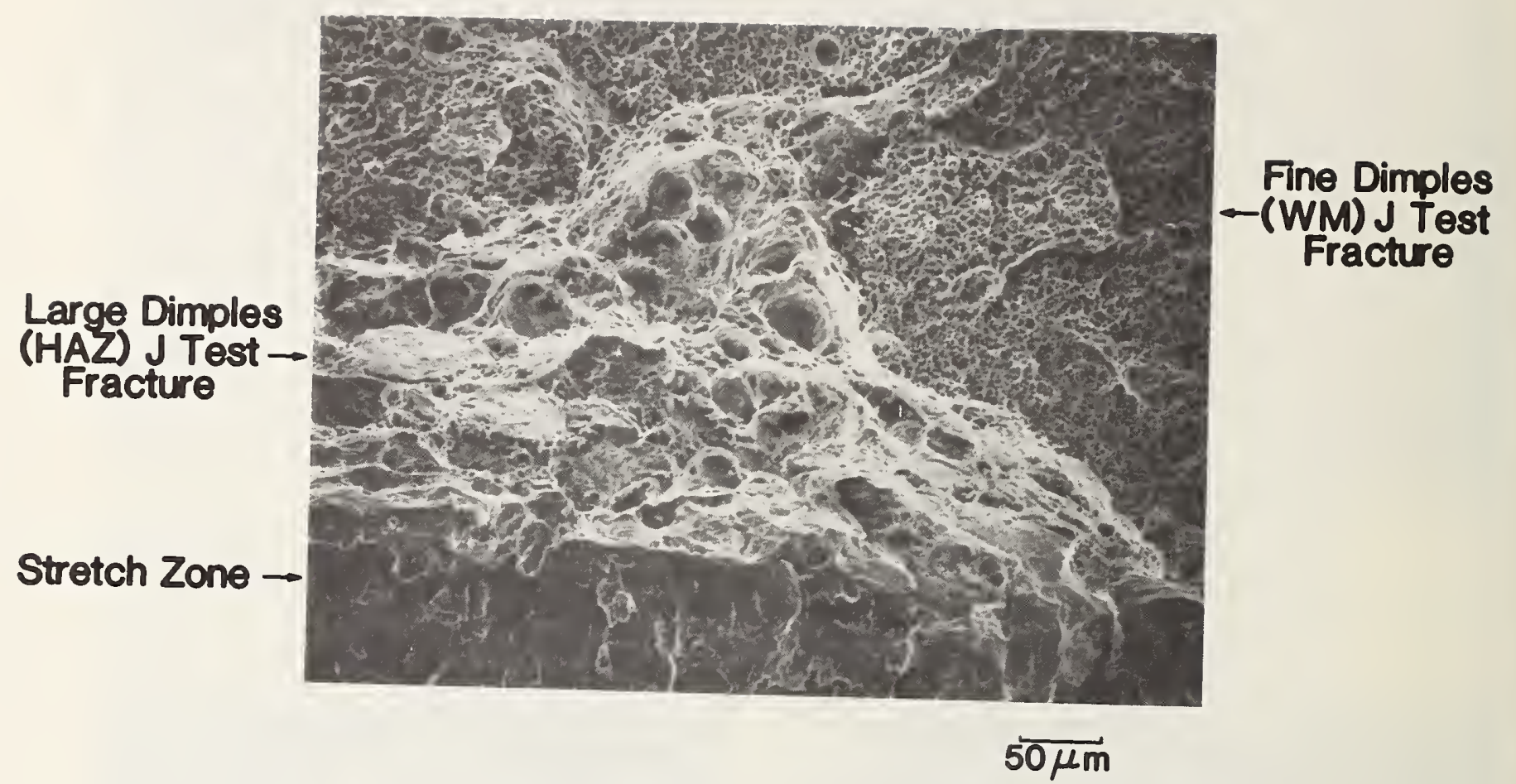

Eigure 14. Macrograph showing a fracture pattern of initiation in the HAZ and propagation in the weld. 


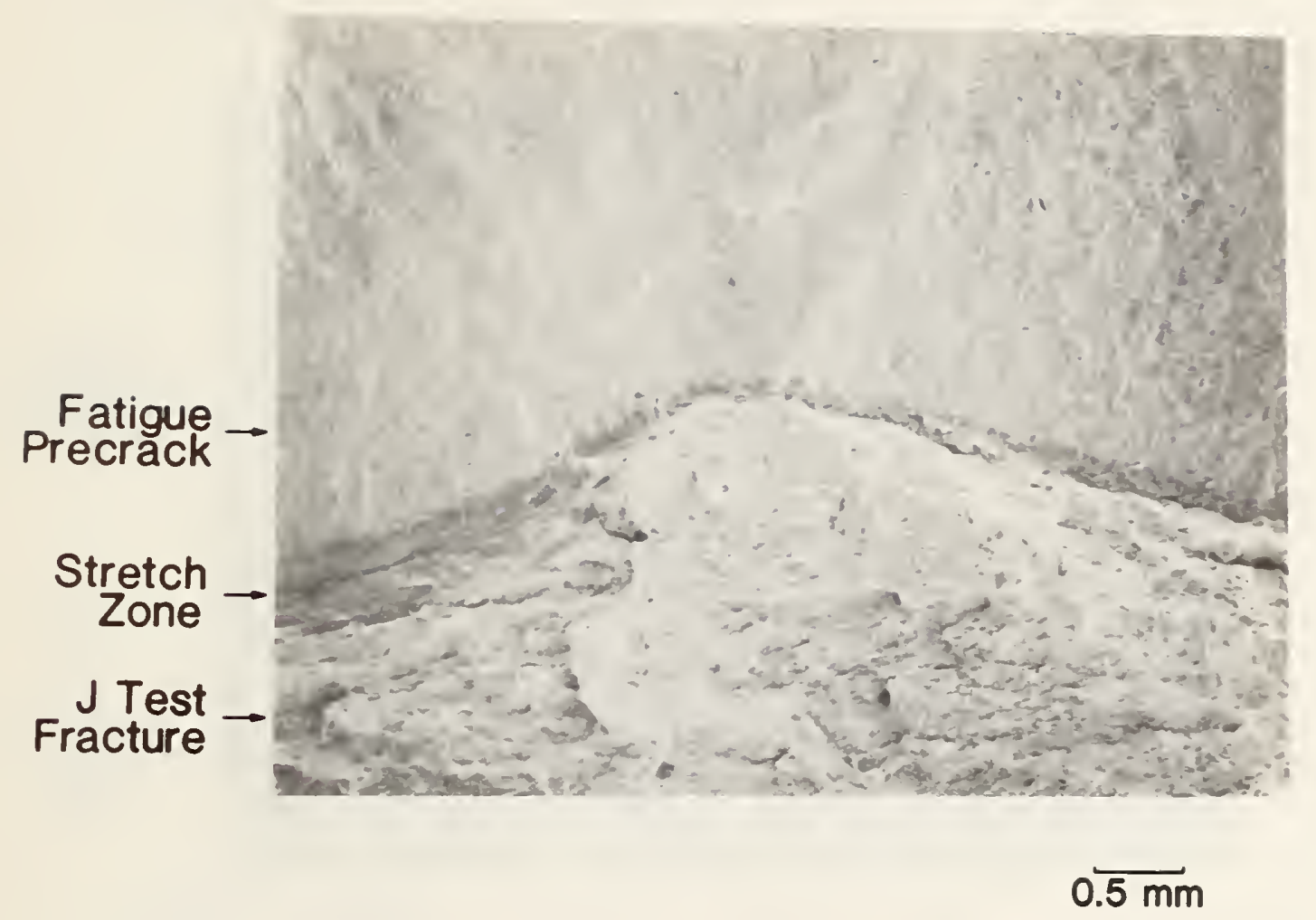

Figure 15. Macrograph showing a fracture pattern of initiation at a weld flaw and propagation in the weld. 


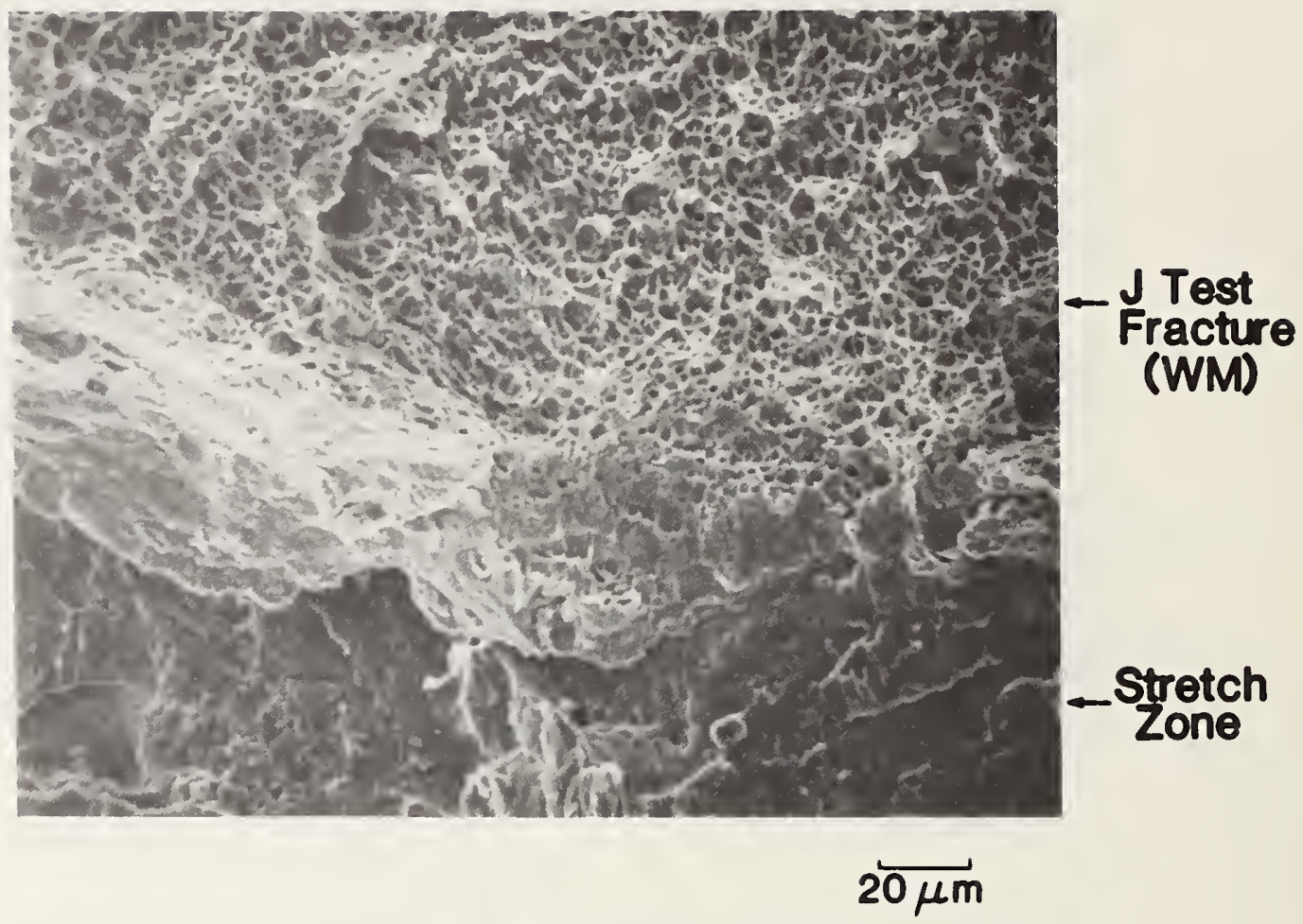

Figure 16. Macrograph showing a fracture pattern of initiation in the weld and propagation in the weld. 


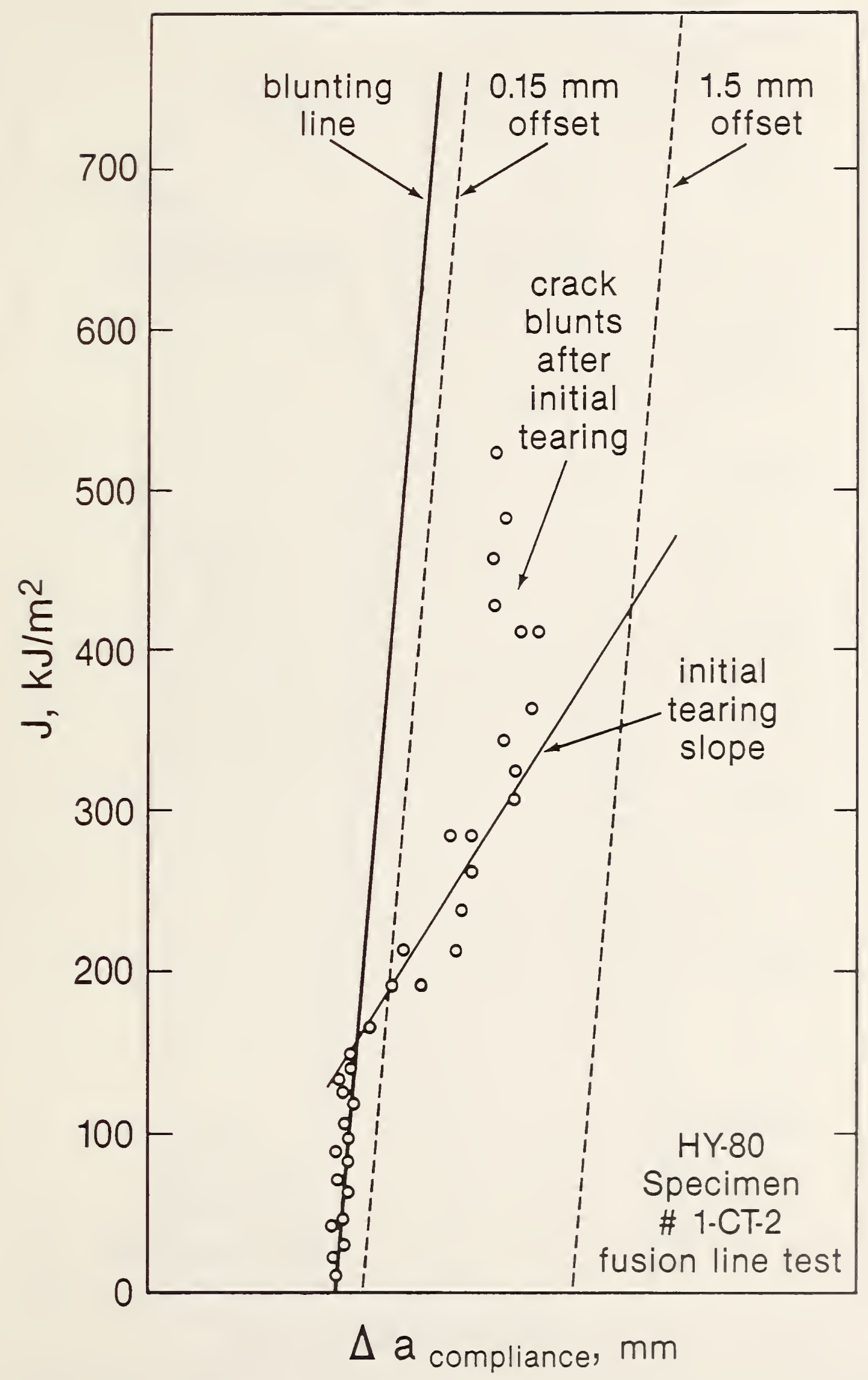

"igure 17. Representative J-R curve for crack initiation dt a flaw. 


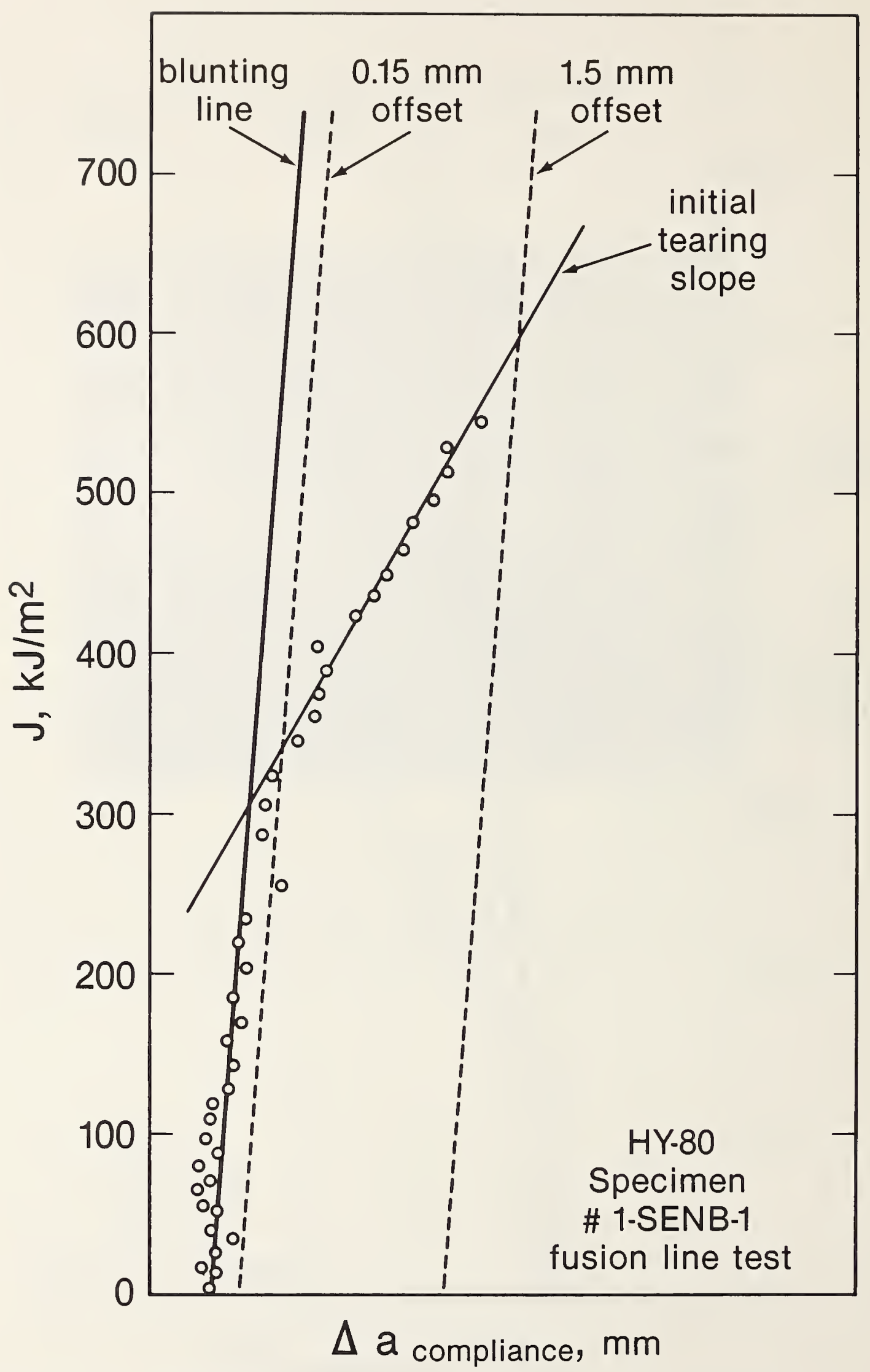

Figure 18. Representative $J-R$ curve for crack initiation in the weld. 


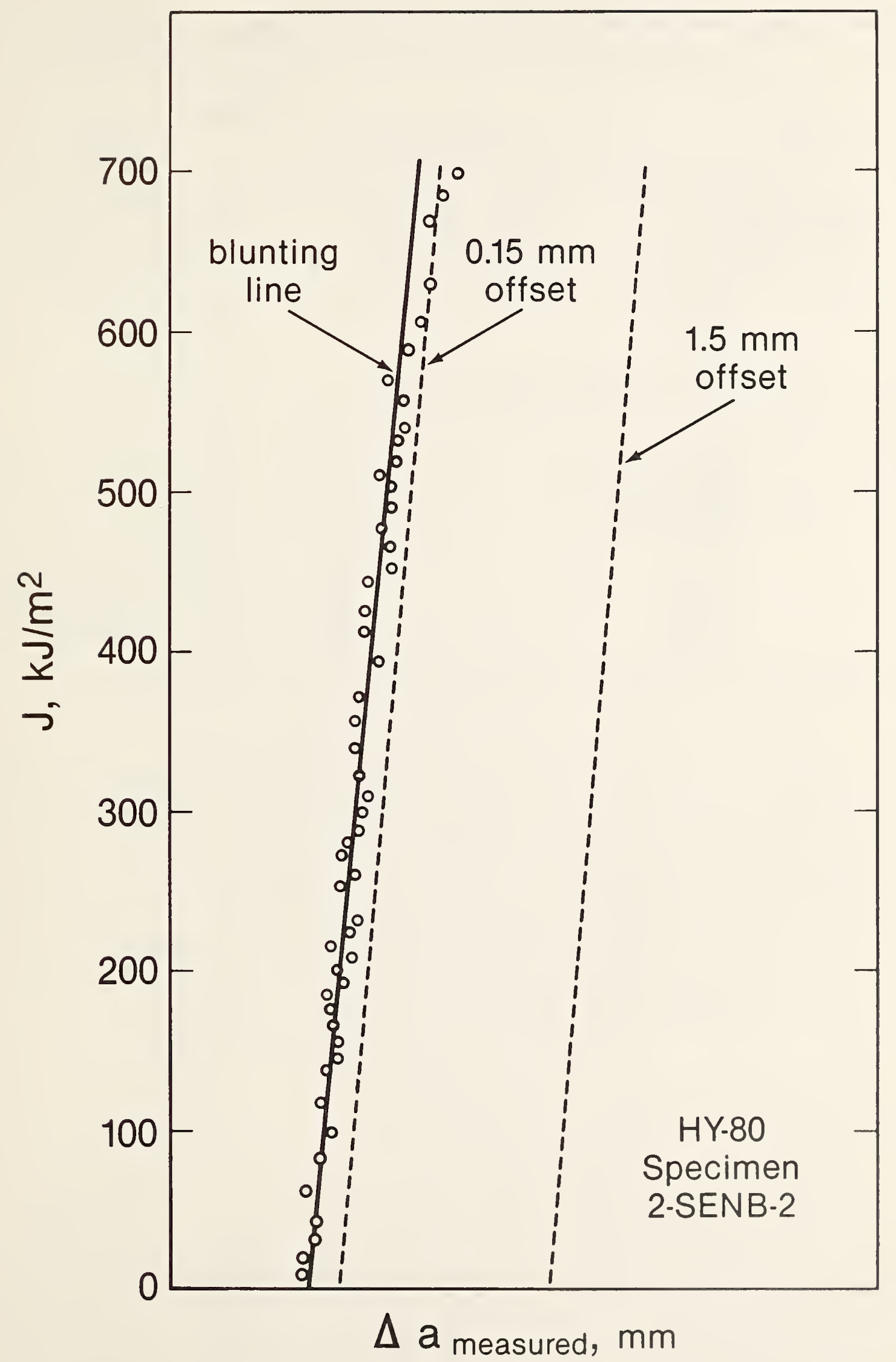

Figure 19. Representative J-R curve for a high toughness weld that was invalid-- it did not meet the requirements of ASTM E 813. 
Table 1. Comparison of CVN absorbed energy for welds and base material

\begin{tabular}{llr} 
Material & Requirement & Toughness \\
\hline GMA electrode & $48 \mathrm{~J}$ at $-51^{\circ} \mathrm{C}$ & $81-153 \mathrm{~J}$ at $-51^{\circ} \mathrm{C}$ \\
SMA electrode & $48 \mathrm{~J}$ at $-51^{\circ} \mathrm{C}$ & $48-103 \mathrm{~J}$ at $-51^{\circ} \mathrm{C}$ \\
HY-80 base material & $48 \mathrm{~J}$ at $-84^{\circ} \mathrm{C}$ & $205 \mathrm{~J}$ at $-84^{\circ} \mathrm{C}$
\end{tabular}

Table 2. Summary of the experimental design

\begin{tabular}{llll} 
Weld & $\begin{array}{c}\text { Torch Oscillation } \\
\text { Amplitude }\end{array}$ & Penetration & Welding System \\
\hline 1 & No & Low & Semiautomatic \\
3 & Yes & Low & Semiautomatic \\
4 & Yes & High & Semiautomatic \\
& Yes & High & Adaptive \\
\hline
\end{tabular}


Table 3. Chemical composition and mechanical properties of 25-mm-thick HY-80 plate (MIL-S-16216J) used for these tests

Chemical Composition

\begin{tabular}{ll} 
Elements & Weight $\%$ \\
\hline C & 0.14 \\
Mn & 0.28 \\
Si & 0.29 \\
P & 0.008 \\
S & 0.002 \\
Cr & 1.32 \\
Ni & 2.42 \\
Mo & 0.30 \\
Al & 0.022 \\
V & 0.002 \\
Ti & 0.001 \\
Cu & 0.16 \\
As & 0.007 \\
Sb & 0.001 \\
Sm & 0.019 \\
\hline
\end{tabular}

Mechanical Properties

\begin{tabular}{ll} 
Yield strength & $625 \mathrm{MPa}$ \\
Tensile strength & $740 \mathrm{MPa}$ \\
Elongation & $48.5 \%$ in $50 \mathrm{~mm}$ \\
Reduction of area & $70.0 \%$ \\
$\mathrm{CVN}^{*}$ & $\mathrm{~T}-268 \mathrm{~J}$ at $-18^{\circ} \mathrm{C}$ \\
& $\mathrm{B}-257 \mathrm{~J}$ at $-18^{\circ} \mathrm{C}$ \\
$\mathrm{CVN}^{*}$ & $\mathrm{~T}-204 \mathrm{~J}$ at $-84^{\circ} \mathrm{C}$ \\
& $\mathrm{B}-206 \mathrm{~J}$ at $-84^{\circ} \mathrm{C}$ \\
\hline
\end{tabular}

${ }^{*} \mathrm{CVN}=$ Charpy $\mathrm{V}$-notch 
Table 4. Chemical composition and mechanical properties of $1.2 \mathrm{~mm}$ diameter MIL $100 S^{-1}$ welding electrode ${ }^{*}$

\section{Chemical Composition}

\begin{tabular}{ll} 
Elements & Weight $\%$ \\
\hline Mn & 0.068 \\
Si & 1.58 \\
P & 0.34 \\
S & 0.008 \\
Cr & 0.003 \\
Ni & 0.11 \\
Mo & 1.72 \\
Al & 0.33 \\
V & 0.01 \\
Ti & 0.01 \\
Zr & 0.01 \\
Cu & 0.02 \\
\hline
\end{tabular}

Mechanical Properties

\begin{tabular}{ll} 
Yield strength & $620 \mathrm{MPa}$ \\
Tensile strength & $740 \mathrm{MPa}$ \\
Elongation & $25.7 \%$ in $50 \mathrm{~mm}$ \\
Reduction of area & $68.7 \%$ \\
CVN & $\mathrm{T}-140 \mathrm{~J}$ at $-18^{\circ} \mathrm{C}$ \\
& $\mathrm{B}-68 \mathrm{~J}$ at $-51^{\circ} \mathrm{C}$ \\
\hline
\end{tabular}

* tested according to MIL-E-23765/2C 
Table 5. Summary of constant welding conditions for the first and subsequent passes for each of the test plates

\begin{tabular}{lll} 
Pass & 1 (root) & $2-10$ \\
\hline Filler Metal & $100 \mathrm{~S}-1$ & $100 \mathrm{~S}-1$ \\
Shielding gas & $\mathrm{Ar}-5 \% \mathrm{CO}_{2}$ & $\mathrm{Ar}-5 \% \mathrm{CO}_{2}$ \\
Torch Gap (mm) & 22 & 22 \\
Weave Width (mm) & 10 & 10 \\
Current (A) & 220 & $280-300$ \\
Voltage (V) & 25 & 190 \\
Travel Speed (mm/min) & 122 & 2.6 \\
Heat input (kJ/mm) & 2.7 & \\
\hline
\end{tabular}


Table 6. Typical weld weave widths for the various weld passes in welds 2 to 4 Weave Width

\begin{tabular}{llllllllll} 
Pass & 1 & 2 & 3 & 4 & 5 & 6 & 7 & 8 & 9 \\
Osc. stroke (mm) & 9.4 & 10.1 & 9.4 & 9.4 & 9.4 & 9.4 & 10.4 & 10.4 & 11.7 \\
Osc. speed (mm/min) & 550 & 710 & 710 & 710 & 710 & 710 & 1000 & 1000 & 1140 \\
\hline
\end{tabular}


Table 7. Tensile properties of the weld metal

\begin{tabular}{lccc} 
Weld & $\begin{array}{c}\text { Yield Strength } \\
0.2 \%(\mathrm{MPa})\end{array}$ & $\begin{array}{c}\text { Jitimate Tensile } \\
\text { Strength }(\mathrm{MPa})\end{array}$ & $\begin{array}{c}\text { Elongation } \\
(\%)\end{array}$ \\
\hline 1 (stringer) & 628 & 707 & 30 \\
2 (weave) & 624 & 707 & 30 \\
3 (weave) & 694 & 746 & 27.5 \\
$4($ weave) & 678 & 753 & 32 \\
$\begin{array}{l}\text { Specification } \\
\text { (MIL-E-23765/2C) }\end{array}$ & $606-703$ & & 19 \\
\hline
\end{tabular}

* minimum required

Table 8. Compositional differences between base material and welding electrode

\begin{tabular}{lll}
\hline Element & $\begin{array}{l}\text { Base } \\
\text { Material } \\
(\text { wt. } \%)\end{array}$ & $\begin{array}{l}\text { Welding } \\
\text { Electrode } \\
\text { (wt. \%) }\end{array}$ \\
\hline $\mathrm{C}$ & 0.14 & 0.068 \\
$\mathrm{Mn}$ & 0.28 & 1.58 \\
\hline
\end{tabular}


Table 9. Charpy $\mathrm{V}$-notch data for the weld metal at $-51^{\circ} \mathrm{C}$

$\begin{array}{lll}\text { Specimen } & \text { Absorbed } & \text { Lateral } \\ & \text { Energy } * & \text { Expansion } \\ & (\mathrm{J}) & (\mathrm{mm})\end{array}$

1 a (stringer) 121

$1 \mathrm{~b}$ (stringer) 118

1 c (stringer) 156

1 d (stringer) 155

1 e (stringer) 122
1.3

1.3

1.7

1.8

1.4

1.5 average
2 a (weave) $\quad 149$

$2 \mathrm{~b}$ (weave) $\quad 171$

2 c (weave) 144

2 d (weave) 147

2 e (weave) 144

134 average

1.4

1.8

1.8

1.7

1.6

1.7

1.7 average

152 average

1.2

1.4

1.5

1.0

1.3

1.3 average

116 average

98
120
115
90
95

$1 \cdot 3$

1.6

1.5

1.2

$1 \cdot 3$

1.4 average

* Specification requirement: $47 \mathrm{~J}$. 
Table 10. Fracture toughness test results for 25-mm compact-tension specimens

\begin{tabular}{|c|c|c|c|c|c|}
\hline Specimen & $\begin{array}{c}\text { Notch } \\
\text { Location }\end{array}$ & $\begin{array}{c}\mathrm{J}_{\mathrm{Q}} \\
\left(\mathrm{kJ} / \mathrm{m}^{2}\right) \\
\end{array}$ & $\begin{array}{c}\mathrm{K}_{\mathrm{Q}}(\mathrm{J}) \\
(\mathrm{MPa} \cdot \sqrt{\mathrm{m}}) \\
\end{array}$ & $\begin{array}{l}\text { Initiation } \\
\text { Site }\end{array}$ & Comments \\
\hline $1-C T-1$ & FL & 370 & 276 & WM & \\
\hline $1-\mathrm{CT}-2$ & FL & 160 & 180 & WM flaw & \\
\hline $1-\mathrm{CT}-3$ & FL & 180 & 190 & WM flaw & \\
\hline $1-C T-W M$ & WM & 600 & 352 & WM & invalid ${ }^{*}$ \\
\hline $2-C T-1$ & EL & 370 & 275 & $\mathrm{HAZ}+W M$ & \\
\hline $2-C T-2$ & FL & 200 & 204 & $\mathrm{HAZ}+\mathrm{WM}$ & \\
\hline $3-C T-1$ & FL & 180 & 182 & WM flaw & \\
\hline $3-C T-2$ & FL & 210 & 207 & WM flaw & \\
\hline $3-\mathrm{CT}-3$ & FL & 250 & 240 & $\mathrm{HAZ}$ & \\
\hline $3-C T-4$ & FL & 230 & 219 & $\mathrm{HAZ}+W M$ & \\
\hline $4-\mathrm{CT}-1$ & FL & 170 & 188 & WM & \\
\hline $4-\mathrm{CT}-2$ & FL & 190 & 200 & WM & \\
\hline 4-CT-WM & WM & 400 & 289 & WM & invalid ${ }^{*}$ \\
\hline $4-C T-B M$ & BM & 640 & 358 & BM & invalid \\
\hline
\end{tabular}

* Specimen thickness and the slope of the tearing line fail to meet ASTM E813 requirements. 
Table 11. Fracture toughness test results for 25-mm single-edge-notch bend spec imens

\begin{tabular}{|c|c|c|c|c|c|}
\hline Specimen & $\begin{array}{c}\text { Notch } \\
\text { Location }\end{array}$ & $\begin{array}{c}J Q_{m} \\
\left(k J m^{2}\right)\end{array}$ & $\begin{array}{c}\mathrm{K}_{\mathrm{Q}}(\mathrm{J}) \\
(\mathrm{MPa} / \mathrm{m}) \\
\end{array}$ & $\begin{array}{l}\text { Initiation } \\
\text { Site }\end{array}$ & Comments \\
\hline 1-SENB-1 & FL & 300 & 248 & WM flaw & \\
\hline 1 -SENB-2 & FL & 480 & 315 & $\mathrm{HAZ}$ & \\
\hline 2-SENB-1 & FL & 310 & 252 & WM & \\
\hline 2-SENB-2 & FL & 400 & 287 & WM & \\
\hline 3-SENB-1 & FL & 210 & 209 & WM flaw & \\
\hline 4-SENB-1 & FL & 230 & 219 & FL flaw & \\
\hline 4-SENB-1 & FL & 320 & 257 & $\mathrm{HAZ}+$ WM Flaw & \\
\hline
\end{tabular}

FL - Fusion-Line 
Table 12. Microhardness traverse across the fusion line of the four welds

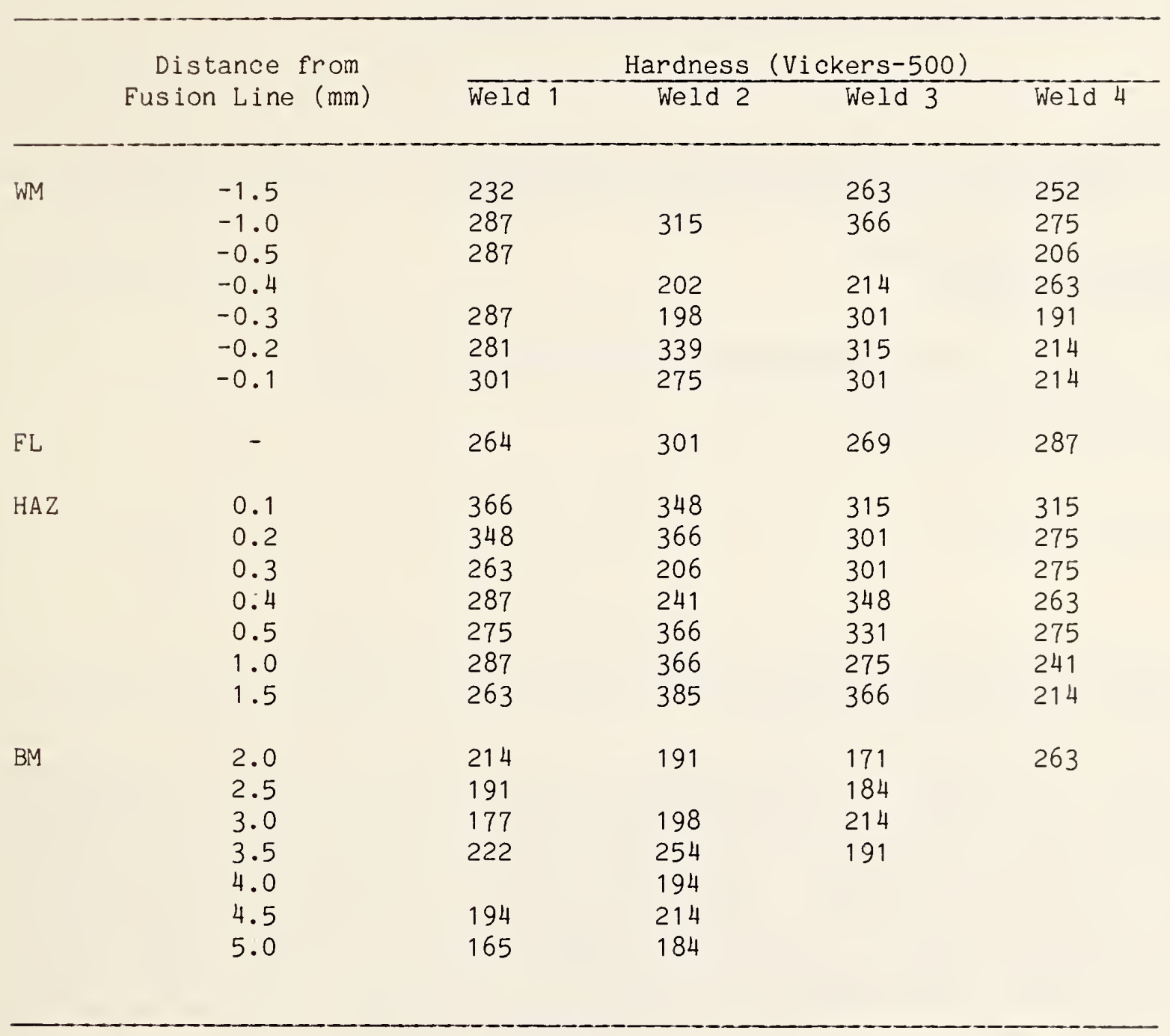


NBS-114A (REV, 2-8C)

\begin{tabular}{|c|c|c|c|}
\hline $\begin{array}{c}\text { U.S. DEPT. OF COMM. } \\
\text { BIBLIOGRAPHIC DATA } \\
\text { SHEET (See instructions) }\end{array}$ & $\begin{array}{c}\text { 1. PUBLICATION OR } \\
\text { REPORT NO. } \\
\text { NBSIR } 86-3043\end{array}$ & 2. Performing Organ. Report No. & $\begin{array}{c}\text { 3. Publication Date } \\
\text { Apri1 } 1986\end{array}$ \\
\hline
\end{tabular}

4. TITLE AND SUBTITLE

Fusion Line Shape versus Toughness in HY-80 GMA welds

5. AUTHOR(S)

T. A. Siewert, R. E. Trevisan, and P. T. Purtscher

6. PERFORMING ORGANIZATION (If joint or other than NBS, see instructions)

NATIONAL BUREAU OF STANDARDS

DEPARTMENT OF COMMERCE

WASHINGTON, D.C. 20234

9. SPONSORING ORGANIZATION NAME AND COMPLETE ADDRESS (Street. City, State, ZIP)

D. W. Taylor Naval Ship R\&D Center

Department of the Navy

10. SUPPLEMENTARY NOTES

Document describes a computer program; SF-185, FIPS Software Summary, is attached.

11. ABSTRACT (A 200-word or less factual summary of most significant information. If document includes a significant bibliography or literature survey. mention it here)

This report describes the effect of the electrode weave procedure on both the fusionline shape and toughness of reduced-gap gas metal arc (GMA) welds. To study the variation in toughness, four GMA welds were produced in 25-mm-thick HY-80 plate using MIL 100S-1 electrode and following the weld procedure listed in the electrode specification, MIL-E-23765/2C. These four welds were used to compare stringer beads with various weave procedures using both manually controlled and adaptively controlled welding systems. All-weld-metal Charpy V-notch (CVN) and tensile tests confirmed that these welds met the requirements for MIL 100S-1 electrodes. An increase in strength from 630 to $680 \mathrm{MPa}$ and a decrease in toughness from 135 to $110 \mathrm{~J}$ were observed for the weave patterns with the greatest penetration into the base material.

Testing of compact tension and single-edge-notch bend specimens at room temperature produced $\mathrm{K}_{\mathrm{Q}}(\mathrm{J})$ fusion line toughness values of 180 to $315 \mathrm{MPa} \cdot \mathrm{m}$, with little variation due to weave procedures. Microstructural examination of the crack-initiation region indicated failures occurred and propagated in the HAZ or in the weld metal, rather than along the fusion line. An etching technique revealed a small number of planar flaws on the fusion-line surface that were not detected with radiography. We conclude that weave procedure substantially modifies the fusion-line shape, can change the weld strength; and has little effect on fusion-line or weld toughness.

12. KEY WORDS (Six to twelve entries; alphabetical order; capitalize only proper names; and separate key words by semicolons)

electrode weaving; fracture toughness; fusion line; gas metal arc welding;

HY-80 ; mechanical properties; weld properties.

\section{AVAILABILITY}

Xnlimited

For Official Distribution. Do Not Release to NTIS

Order From Superintendent of Documents, U.S. Government Printing Office, Washington, D.C. 20402.

14. NO. OF PRINTED PAGES

48

15. Price

X] Order From National Technical Information Service (NTIS), Springfield, VA. 22161 

